\title{
Low-solubility particles and a Trojan-horse type mechanism of toxicity: the case of cobalt oxide on human lung cells
}

\author{
Richard Ortega ${ }^{1,2^{*}}$, Carole Bresson ${ }^{3}$, Carine Darolles ${ }^{4}$, Céline Gautier ${ }^{5}$, Stéphane Roudeau ${ }^{1,2}$, Laura Perrin ${ }^{1,2}$, \\ Myriam Janin ${ }^{3,7}$, Magali Floriani ${ }^{6}$, Valérie Aloin ${ }^{4}$, Asuncion Carmona ${ }^{1,2}$ and Véronique Malard ${ }^{4^{*}}$
}

\begin{abstract}
Background: The mechanisms of toxicity of metal oxide particles towards lung cells are far from being understood. In particular, the relative contribution of intracellular particulate versus solubilized fractions is rarely considered as it is very challenging to assess, especially for low-solubility particles such as cobalt oxide $\left(\mathrm{CO}_{3} \mathrm{O}_{4}\right)$.

Methods: This study was possible owing to two highly sensitive, independent, analytical techniques, based on single-cell analysis, using ion beam microanalysis, and on bulk analysis of cell lysates, using mass spectrometry.

Results: Our study shows that cobalt oxide particles, of very low solubility in the culture medium, are readily incorporated by BEAS-2B human lung cells through endocytosis via the clathrin-dependent pathway. They are partially solubilized at low pH within lysosomes, leading to cobalt ions release. Solubilized cobalt was detected within the cytoplasm and the nucleus. As expected from these low-solubility particles, the intracellular solubilized cobalt content is small compared with the intracellular particulate cobalt content, in the parts-per-thousand range or below. However, we were able to demonstrate that this minute fraction of intracellular solubilized cobalt is responsible for the overall toxicity.
\end{abstract}

Conclusions: Cobalt oxide particles are readily internalized by pulmonary cells via the endo-lysosomal pathway and can lead, through a Trojan-horse mechanism, to intracellular release of toxic metal ions over long periods of time, involving specific toxicity.

Keywords: Toxicity, Lung cells, Cobalt oxide, Particles, Endocytosis, Lysosome, Intracellular solubilization, PIXE, ICP-MS

\section{Background}

Inhalation of cobalt oxide particles can lead to adverse lung effects, mainly as a result of occupational exposure to dust and welding fumes [1-3], including exposure to radioactive cobalt oxide particles in the nuclear industry [4]. Environmental exposure to cobalt oxide particles is associated with airborne particulate matter as a consequence of the combustion of cobalt sources, which generate primarily cobalt oxides [5]. No data are yet available concerning the toxicity of cobalt oxide particles

\footnotetext{
* Correspondence: ortega@cenbg.in2p3.fr; veronique.malard@cea.fr 'Univ. Bordeaux, CENBG, UMR 5797, Gradignan F-33170, France ${ }^{4}$ CEA, DSV, IBEB, Lab Biochim System Perturb, Bagnols-sur-Cèze F-30207, France

Full list of author information is available at the end of the article
}

similar to those inhaled in case of accidental occupational contamination in nuclear power plants. However, the increasing industrial use of cobalt nanoparticles has led to many recent in vitro toxicological studies [6-13]. The main chemical forms of cobalt micro- and nanoparticles studied are metallic cobalt, cobalt (II) oxide (CoO), and cobalt (II,III) oxide $\left(\mathrm{Co}_{3} \mathrm{O}_{4}\right)$. These differ greatly in their solubilities, for example more than $50 \%$ of metallic cobalt microparticles are solubilized in culture medium after $72 \mathrm{~h}$ [6], whereas cobalt oxide microparticles are almost insoluble in water or culture medium [1,14].

The chemical and physical properties of metal particles drastically influence their toxic effects [12,15-17]. Solubilization of the particles, leading to cytotoxic effects related to the free metal ions released and/or the direct 
toxic effects of metal oxide micro- and nanoparticles through oxidative stress, are among the major mechanisms suggested to be involved at the cellular level. The more-soluble metallic cobalt nanoparticles induce cytotoxicity, ROS formation, and genotoxicity to a greater extent than cobalt ions $[6,8,9]$. The involvement of dissolution processes in metallic cobalt particle cytotoxicity has been clearly shown for these readily soluble particles $[6,8,9,11]$. The less-soluble cobalt oxide nanoparticles have been shown to be less toxic than cobalt ions [10], but to cause rapid induction of ROS, with ROS levels higher than those induced by cobalt ions $[10,11,13]$. Although cobalt oxide particles exhibit a low toxicity in vitro, they could lead to long-term adverse effects to lung cells in vivo, as they have long retention times in the lung. A small proportion of cobalt oxide particles can remain in the lung for several months or years after inhalation [1,18-20]. For instance, lung retention was $45 \%$ of the initial lung deposit six months after human exposure to $0.8 \mu \mathrm{m} \mathrm{Co}_{3} \mathrm{O}_{4}$ particles [21]. A Trojan-horse type mechanism has been proposed to explain the toxicity of cobalt oxide particles [11], resulting in partial solubilization of particles within cells, especially at low $\mathrm{pH}$ within the lysosome, as suggested by in vitro studies $[14,22]$. The major questions that remain to be answered are (i) what amount of cobalt is solubilized in human lung cells, and (ii) is this amount responsible for particle toxicity?

The origin of the toxicity of low-solubility compounds such as cobalt oxide particles is far from being understood and remains very challenging. In toxicological studies, only the extracellular solubilized fraction of the cobalt oxide particles has so far been measured [10,13], showing a very low amount of cobalt released into the culture medium. Although the investigation of particle behavior in culture media is of special relevance for toxicological studies, deeper studies related to the cellular uptake, intracellular solubilization, and behavior of particles are crucial to gain insight into the associated particle toxicity mechanisms.

In this work, we investigated cobalt oxide particle $\left(\mathrm{Co}_{3} \mathrm{O}_{4}\right)$ toxicity on BEAS-2B human lung cells, and used high-sensitivity analytical techniques that allowed for the first time the discrimination between intracellular solubilized cobalt and non solubilized cobalt in its particulate form. BEAS-2B is a non tumorigenic immortalized cell line that has proven to be a useful model of the airway epithelium for in vitro studies of normal lung tissues [23]. A recent study has shown that BEAS-2B cells exhibited the highest homology in gene expression pattern with primary cells and the lowest number of deregulated genes compared with non tumoral lung tissues [24]. Our choice of $\mathrm{Co}_{3} \mathrm{O}_{4}$ particles was motivated by several factors: the good knowledge of the toxicity associated with the soluble cobalt compound $\left(\mathrm{CoCl}_{2}\right)$ in this cellular model [25]; the very low levels of cobalt in cells under physiological conditions, contrary to endogenous metals such as $\mathrm{Fe}$ or $\mathrm{Zn}$; the submicrometric, but not nanometric, size of the particles, avoiding the real 'nano-' driven toxic effects, although our model is also suited to nanoparticle aggregates; and the known low solubility of $\mathrm{Co}_{3} \mathrm{O}_{4}$ particles, making them a good model for most metal oxide particles. Finally, $\mathrm{Co}_{3} \mathrm{O}_{4}$ particles of this size range are well suited for mimicking radioactive particles encountered in the nuclear industry [19].

We first characterized the size and aggregation of particles and assessed their cytotoxicity on BEAS-2B and also on primary human bronchial (NHBE) cells using ATPquantification and clonogenic assays. The solubilization ratio of the cobalt particles in the culture and artificial lysosomal fluid (ALF) was assessed. We then followed particle internalization, and identified their internalization pathways. We determined the amount of intracellular solubilized and particulate cobalt fractions upon exposure to various concentrations of cobalt oxide particles, and the in situ distribution of solubilized cobalt among the subcellular compartments, such as the cytoplasm and nucleus. Finally, we were able to evaluate for the first time the relative contributions of intracellular solubilized and particulate cobalt fractions on overall cytotoxicity. This methodology can now be applied to the study of other metal particles, especially those containing exogenous elements not present as natural components of the cells.

\section{Results and discussion}

\section{Cobalt oxide particle characterization}

Our purpose was to study the toxicity of particles representative of those involved in the case of accidental inhalation in nuclear power plants. We thus selected the particles according to their estimated average diameter [19]. Physical characterization of these particles had been performed, in part, previously [26]. The morphology of the $\mathrm{Co}_{3} \mathrm{O}_{4}$ particles is shown in Figure 1 panel A, on representative transmission electron microscopy (TEM) images). These images show that the $\mathrm{Co}_{3} \mathrm{O}_{4}$ particles were mainly aggregated, and exhibited a polyhedral structure of heterogeneous size, in the 100 to $400 \mathrm{~nm}$ range. Energy dispersive X-ray spectroscopy (EDX) microanalysis of cobalt particles showed that peaks of Co were predominant (Figure 1, Panel B). The presence of $\mathrm{Cu}$ was due to the TEM grid used. These results confirmed the high purity of the particles indicated by the supplier (98.4\%). These particles are thus suitable for mimicking real cases of contamination, as the particle size in cases of accidental contamination has been estimated to be in the range of 210-850 nm, with a mean value of $410 \mathrm{~nm}$ [19]. The distribution of cobalt particles size in LHC9 culture medium 

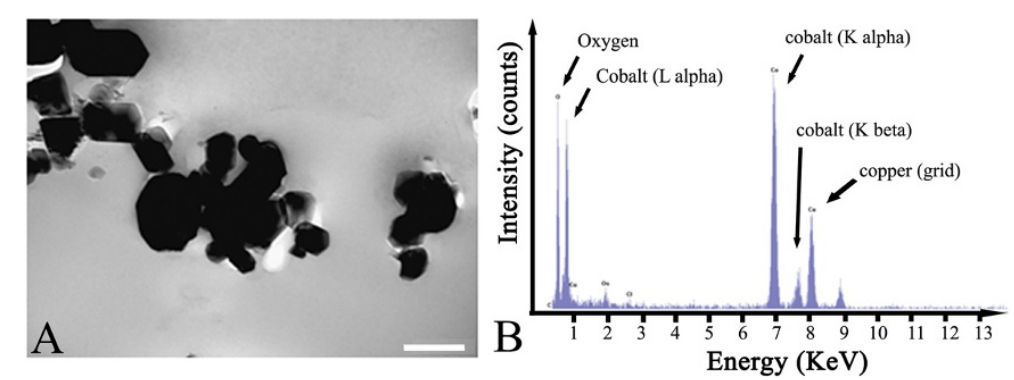

Figure 1 Transmission electron microscopy image of cobalt oxide particles (scale bar: $200 \mathrm{~nm}$ ) (A) and energy dispersive X-ray spectroscopy microanalysis of cobalt oxide particles (B).

suspensions was determined by dynamic light scattering (DLS) measurements. The average size ( $\mathrm{z}$-average) and the polydispersity index were determined before and after a 15 min sonication. The data summarized in Table 1 indicate a strong aggregation in the culture medium before sonication. A 15 min sonication was sufficient to disrupt aggregates, the average size of the cobalt oxide particles being $372 \mathrm{~nm}$, with a decreased polydispersity (0.24). In the basal medium (LHCB), which is protein-free, deagglomeration by sonication was not efficient (data not shown) suggesting that the protein corona facilitates deagglomeration [17]. Latex beads (LB-3, $400 \mathrm{~nm}$ size), used throughout the study as negative controls, also aggregated in LHC9 medium. Deagglomeration was obtained after a very short sonication (1 $\mathrm{min})$, leading to monodispersed particles of $408 \mathrm{~nm}$ (Table 1). These particles, exhibiting a size very similar to that of cobalt particles, were thus a relevant control.

\section{Cytotoxicity of cobalt oxide particles versus cytotoxicity of cobalt chloride}

The cytotoxicity of cobalt oxide particles was evaluated on BEAS-2B cells by measuring the CellTiter-Glo assay after $72 \mathrm{~h}$ exposure to increasing concentrations of $\mathrm{Co}_{3} \mathrm{O}_{4}$ particles in LHC9 $\left(0-1000 \mu \mathrm{g} \cdot \mathrm{mL}^{-1} \mathrm{Co}\right)$. Because of the low level of toxicity of cobalt oxide particles [26], we investigated a wide range of concentrations. In parallel, the cytotoxicity of LB-3 latex beads was evaluated for similar concentrations $\left(0-1000 \mu \mathrm{g} \cdot \mathrm{mL}^{-1}\right)$. After $72 \mathrm{~h}$ exposure, the sedimentation of $400 \mathrm{~nm}$ cobalt oxide particles, as well as latex beads, was fully achieved which validate the cytotoxicity results obtained for these particles suspensions, all the particles being available to the adhering cells. As shown in Figure 2, a dose-dependent decrease in ATP content was observed after cell exposure to $\mathrm{Co}_{3} \mathrm{O}_{4}$ particles. The IC50 (concentration of cobalt for which the ATP content is $50 \%$ lower than for non exposed cells) was found to be $170 \mu \mathrm{g} \cdot \mathrm{mL}^{-1}$ Co. The IC25 and IC75 values were, respectively, 50 and $600 \mu \mathrm{g} \cdot \mathrm{mL}^{-1}$ Co. These results show that the toxicity of such cobalt particles is much lower than that induced by soluble cobalt chloride with similar exposure times (72 h), with respective IC25, IC50 and IC75 values of 2.9, 4.4 and $6.5 \mu \mathrm{g} \cdot \mathrm{mL}^{-1}$ Co (Figure 2). These results also demonstrate that at $72 \mathrm{~h}$ the toxicity of cobalt chloride is higher than after $24 \mathrm{~h}$ exposure [25]. Concerning latex beads, the cell viability decreased very slightly, reaching $75 \%$ at the highest concentration, rendering the IC50 determination impossible. This indicates that the toxicity of cobalt particles is not related to their physical properties (size, shape).

We also carried out a clonogenic assay, which has recently been described as a reference method for testing the cytotoxicity of $\mathrm{Co}_{3} \mathrm{O}_{4}$ microparticles [26]. Figure 2B shows the results obtained as colony forming efficiency counts after exposure of BEAS-2B and NHBE cells to various concentrations of $\mathrm{Co}_{3} \mathrm{O}_{4}$ particles $(0-1000 \mu \mathrm{g}$. $\left.\mathrm{mL}^{-1} \mathrm{Co}\right)$. We found that the number of colonies was significantly reduced upon exposure to $\mathrm{Co}_{3} \mathrm{O}_{4}$ particles. We did not formally count the number of cells of each colony but, as highlighted in Figure 2 panel B, we noticed a decrease in their size, thus indicating cytostaticity. After

Table 1 Average size of cobalt oxide particles and latex beads, before and after sonication in LHC9 medium

\begin{tabular}{|c|c|c|c|c|}
\hline & \multicolumn{2}{|c|}{ Before sonication } & \multicolumn{2}{|c|}{ After sonication } \\
\hline & Average size (nm) & Polydispersity index (PDI) & Average size $(\mathrm{nm})$ & Polydispersity index (PDI) \\
\hline $\mathrm{CO}_{3} \mathrm{O}_{4}^{*}$ & $1843 \pm 279$ & $0.44 \pm 0.05$ & $372 \pm 101$ & $0.24 \pm 0.07$ \\
\hline Latex beads $(\text { LB-3) })^{* *}$ & $1024 \pm 34$ & $0.26 \pm 0.03$ & $408 \pm 14$ & $0.06 \pm 0.03$ \\
\hline
\end{tabular}

$\left({ }^{*} 15\right.$ min sonication $n=6,{ }^{* *} 1$ min sonication $\left.n=3\right)$. 

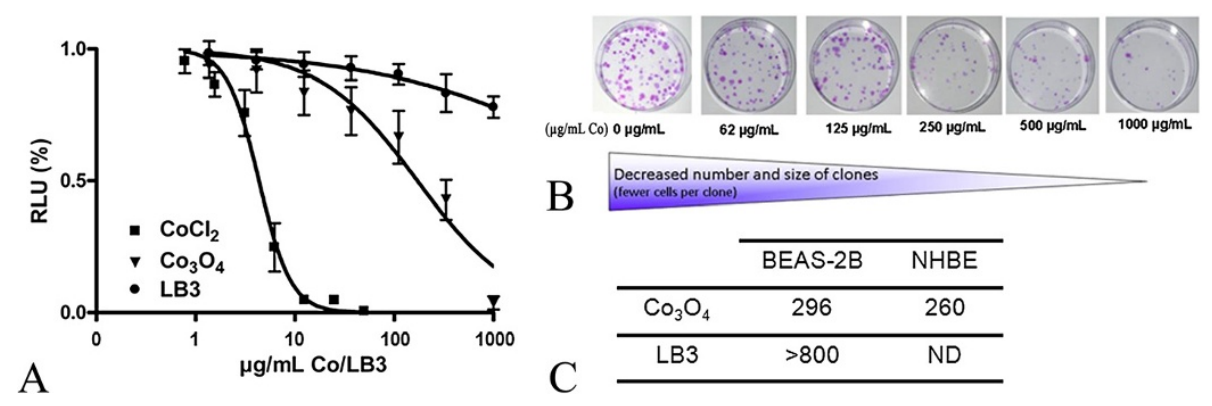

Figure 2 Toxicity of $\mathrm{Co}_{3} \mathrm{O}_{4}$ particles on BEAS-2B and NHBE primary cells. CellTiter-Glo assay (ATP measurement) (A). BEAS-2B cells were exposed to $\mathrm{CO}_{3} \mathrm{O}_{4}$ particles $\left(0-1000 \mu \mathrm{g} \cdot \mathrm{mL}^{-1} \mathrm{Co}\right)$, latex beads $L B-3\left(0-1000 \mu \mathrm{g} \cdot \mathrm{mL}^{-1}\right)$ as a negative control, or soluble cobalt $\left(\mathrm{CoCl}_{2}\right)$ for $72 \mathrm{~h}$ $\left(0-50 \mu \mathrm{g} \cdot \mathrm{mL}^{-1} \mathrm{Co}\right)$. The cellular ATP content was then evaluated (RLU, Relative Light Unit). Results were obtained from a minimum of three independent experiments, each performed in quadruplicate. Clonogenic assay (proliferation) (B). Example of $\mathrm{CO}_{3} \mathrm{O}_{4}$ particle effects on colony formation of BEAS-2B cells $\left(\mu \mathrm{g} \cdot \mathrm{mL}^{-1} \mathrm{Co}\right)$. Colony numbers were determined following a $24 \mathrm{~h}$ exposure to $\mathrm{CO}_{3} \mathrm{O}_{4}$ particles and LB-3 $\left(0-1000 \mu \mathrm{g} \cdot \mathrm{mL}^{-1}\right.$ $\mathrm{Co}$ and LB-3, respectively) and ten days of culture (time period needed to form colonies). Results were obtained from three to six biological replicates. IC50 ( $\mu \mathrm{g} \cdot \mathrm{mL}^{-1} \mathrm{Co}$ and LB-3, respectively) values obtained after exposure of BEAS-2B and NHBE cells to $\mathrm{CO}_{3} \mathrm{O}_{4}$ particles and latex beads (C).

$24 \mathrm{~h}$ exposure to $\mathrm{Co}_{3} \mathrm{O}_{4}$ particles, followed by 10 days of culture, the IC50 was estimated to be $296 \mu \mathrm{g} \cdot \mathrm{mL}^{-1}$ Co using this clonogenic assay. These results are consistent with the data obtained using the CellTiter-Glo assay. In addition, these results were validated on NHBE cells (normal bronchial cells), showing that our in vitro model represents primary human lung cells quite well in terms of toxicity (Figure 2 panel C). Latex beads were not cytotoxic $\left(\mathrm{IC} 50>800 \mu \mathrm{g} \cdot \mathrm{mL}^{-1}\right)$.

\section{Cobalt oxide particles solubilization in extracellular medium}

Knowledge of the solubilization level of oxide particles able to occur in the extracellular medium, as well as in the intracellular medium, is an essential point in elucidating the mechanisms of toxicity. The potentially released metal ions in the culture medium could be responsible for specific uptake and toxicity mechanisms of soluble ions. For example, it has been observed in human WTHBF-6 bronchial cells that the toxicity of low-solubility lead chromate particles was induced by their extracellular dissolution rather than by their internalization or intracellular dissolution [27].

The percentage of cobalt solubilization, i. e. the release of ionic cobalt from the particles, in LHC9 culture medium was determined for $\mathrm{Co}_{3} \mathrm{O}_{4}$ particle suspensions corresponding to 50,170 and $600 \mu \mathrm{g} \cdot \mathrm{mL}^{-1}$ cobalt concentrations (IC25, IC50 and IC75), after incubation periods of three days and seven days (Figure 3 panel A). After incubation, the concentration of solubilized cobalt was measured by ICP-AES/MS (inductively coupled plasma - atomic emission spectroscopy/mass spectrometry). After three days, the dissolution ratios were $0.28 \%, 0.21 \%$ and $0.14 \%$ for IC25, IC50 and IC75, respectively. These values were only slightly higher after seven days incubation, ranging from $0.27 \%$ to $0.42 \%$. Although the particle dissolution capabilities are influenced by the medium type [28], this result was expected as cobalt oxide particles are only very slightly soluble at neutral $\mathrm{pH}$, such as in LHC9 culture medium. For example, $\mathrm{Co}_{3} \mathrm{O}_{4}$ nanoparticle solubilization ranged from $0.03 \%$ to $0.65 \%$ after $72 \mathrm{~h}$, for $\mathrm{Co}_{3} \mathrm{O}_{4}$ suspensions corresponding to $88 \mu \mathrm{g} \cdot \mathrm{mL}^{-1}$ cobalt in different culture media and conditions of incubation [10], and was $0.22 \%$ after $24 \mathrm{~h}$ in DMEM for CoO nanoparticles [12]. In these studies, it was stated that the solubilization is not dependent on particle size. In contrast, cobalt metal nanoparticles/microparticles are more able to dissolve in water and different culture media, at least $44 \%$ after $72 \mathrm{~h}$ in DMEM $[6,8,29]$ and $40 \%$ after $48 \mathrm{~h}$ in RPMI medium [30].

In our case, the extracellular cobalt ion content released from $\mathrm{Co}_{3} \mathrm{O}_{4}$ particles in LHC9 medium was too low - i.e. $0.11 \mu$ g.mL ${ }^{-1}$ (Table 2) at IC25 (suspensions of $\mathrm{Co}_{3} \mathrm{O}_{4}$ particles corresponding to $\left.50 \mu \mathrm{g} \cdot \mathrm{mL}^{-1} \mathrm{Co}\right)-$ to induce any toxicity on BEAS-2B cells. This concentration is much lower, by almost a factor of 30 , than the corresponding concentration of soluble cobalt chloride at IC25 for $72 \mathrm{~h}$ exposure, $2.9 \mu \mathrm{g} \cdot \mathrm{mL}^{-1}$ (Figure 2). It can be concluded that the toxicity of cobalt oxide particles on BEAS-2B cells is not due to their extracellular dissolution. Although our study applies to microparticles, this result is in good agreement with what has been suggested regarding $\mathrm{Co}_{3} \mathrm{O}_{4}$ nanoparticles $[10,13]$.

However, cobalt oxide particles are readily solubilized at more acidic pHs such as in ALF medium, an artificial lysosomal fluid mimicking the lysosomal medium, with a $\mathrm{pH}$ of 4.5. After their intracellular accumulation, 


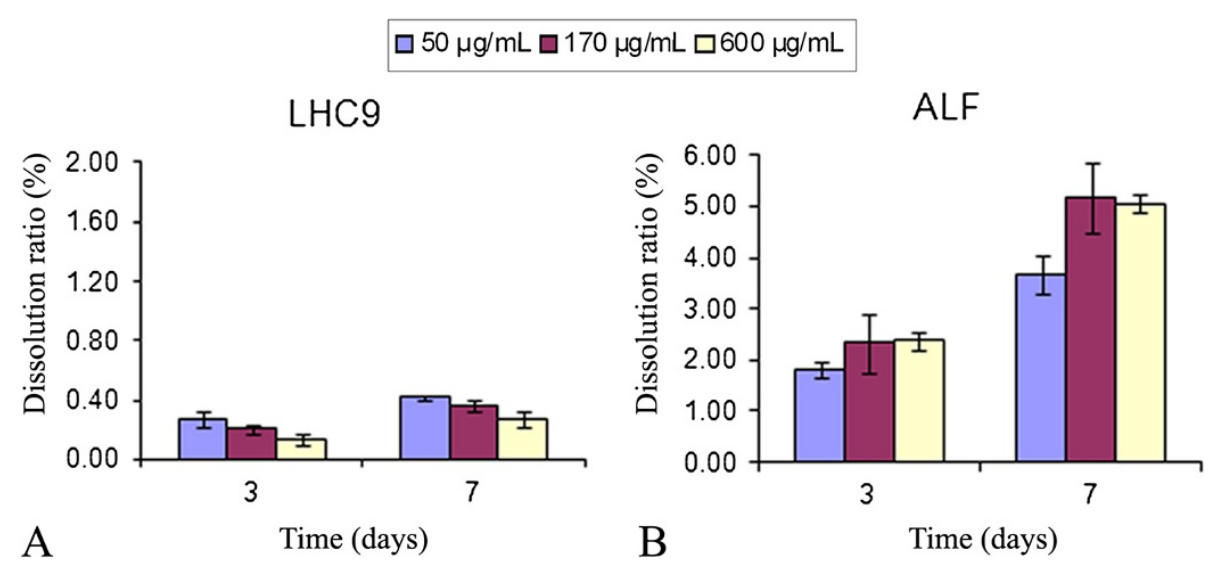

Figure 3 Cobalt oxide solubilization ratios in LHC9 medium (A) and artificial lysosomal fluid (ALF) (B), for $\mathrm{Co}_{3} \mathrm{O}_{4}$ particle suspensions corresponding to IC25, IC50 and IC75 concentrations of cobalt, after $72 \mathrm{~h}$ and 7 days.

particles are often stored in lysosomal vacuoles where intracellular dissolution can occur, and this involves a higher toxicity than the same concentration of free metal ions, according to the "Trojan-horse" type mechanism $[11,31,32]$. The impact of $\mathrm{pH}$ on the dissolution ratio of cobalt oxide particles in various media has already been investigated. $\mathrm{Co}_{3} \mathrm{O}_{4}$ oxide particles dissolve faster at $\mathrm{pH} 4.5$ than at higher $\mathrm{pH}$ [14]. An increase in $\mathrm{Co}_{3} \mathrm{O}_{4}$ particle dissolution has been observed in simple media at $\mathrm{pH}$ around $5[14,22]$ and reached $10 \%$ after $48 \mathrm{~h}$ in acetate buffer at $\mathrm{pH} 4$ [22]. In ALF medium, $\mathrm{Co}_{3} \mathrm{O}_{4}$ particles exhibit $1.6 \%$ solubility at pH 5.5 after a 24 h incubation period [33]. In our study, the solubilization ratio of $\mathrm{Co}_{3} \mathrm{O}_{4}$ particles in ALF medium was about $2 \%$ after three days and up to $5 \%$ after seven days (Figure 3 panel B), which is in good agreement with published data. Our results, together with published data, suggest that $\mathrm{Co}_{3} \mathrm{O}_{4}$ particles could enter lung cells and undergo intracellular solubilization in the lysosomal compartment, to exert toxicity through a Trojan-horse-type mechanism.

Cobalt oxide particle uptake by BEAS-2B cells

BEAS-2B cells were incubated with $\mathrm{Co}_{3} \mathrm{O}_{4}$ particles $\left(200 \mu \mathrm{g} \cdot \mathrm{mL}^{-1} \mathrm{Co}\right)$ and their uptake was monitored through the increase in SSC (side scatter). As reported in Figure 4 panel A, a significant increase in SSC was observed, and also for LB-3 control latex beads with a size similar to the cobalt particles. The uptake of cobalt oxide particles increased with time (Figure 4, panel B). A noticeable increase in cell granulometry was observed by flow cytometry after only $30 \mathrm{~min}$ exposure. This result indicates that cobalt oxide particles were taken up by BEAS-2B cells in a time-dependent manner.

To better delineate the role of each pathway in the cell internalization of cobalt oxide particles, BEAS-2B cells were treated with known biochemical inhibitors of energy-dependent processes, clathrin-mediated endocytosis, caveolae-mediated endocytosis, and macropinocytosis. We first verified that the chosen inhibitors did not induce any significant cellular toxicity on the BEAS-2B cells under our experimental conditions. The percentage of cells labeled with propidium iodide was less than $10 \%$ (data not shown). Figure 5 shows the internalization of $\mathrm{Co}_{3} \mathrm{O}_{4}$ particles in the presence of these inhibitors, as monitored by flow cytometry. Cytochalasin $\mathrm{B}$, which is an inhibitor of actin polymerization, is an inhibitor of macropinocytosis/phagocytosis. In the presence of this drug, the uptake of cobalt oxide particles was unchanged, meaning that phagocytosis or macropinocytosis were not involved in cobalt internalization. Figure 5 shows that amiloride, an $\mathrm{Na}^{+} / \mathrm{H}^{+}$exchange inhibitor that selectively blocks macropinocytosis [34], also did not inhibit particle

Table 2 Solubilized extracellular and intracellular cobalt content, and intracellular zinc content, measured by ICP-MS, after exposure of BEAS-2B cells to $\mathrm{Co}_{3} \mathrm{O}_{4}$ particles for $72 \mathrm{~h}$

\begin{tabular}{cccc}
\hline Co exposure concentration $\left(\boldsymbol{\mu g} \cdot \mathbf{m L}^{-\mathbf{1}}\right.$ ) & Extracellular solubilized Co $\left(\boldsymbol{\mu g} \cdot \mathbf{m L}^{-\mathbf{1}}\right.$ ) & Intracellular solubilized Co (fg/cell) & Intracellular $\mathbf{Z n}(\mathbf{f g} / \mathbf{c e l l})$ \\
\hline Control & 0 & $0.4 \pm 0.1$ & $57 \pm 17$ \\
IC25 & $0.11 \pm 0.01$ & $6.5 \pm 2.0$ & $103 \pm 31$ \\
IC50 & $0.29 \pm 0.02$ & $16.5 \pm 5.0$ & $135 \pm 40$ \\
\hline
\end{tabular}




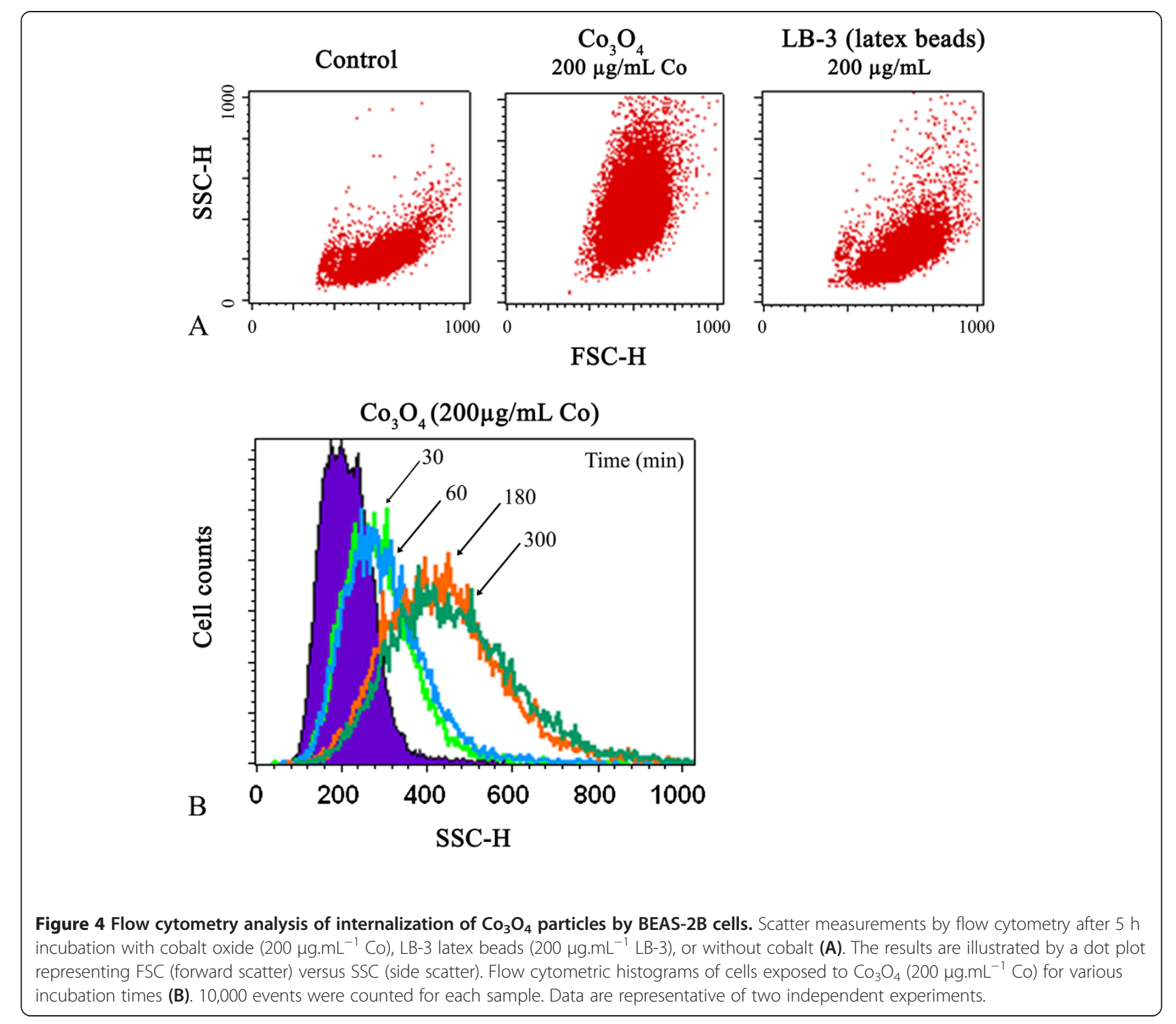

uptake. This result confirmed that macropinocytosis is not responsible for cobalt internalization. Methyl$\beta$-cyclodextrin is a cyclic heptasaccharide known to sequester and alter cholesterol-rich domains within the plasma membrane. This drug is an inhibitor of caveolae-mediated endocytosis. In the presence of this drug, similar results were obtained as shown in Figure 5. This indicates that caveolae-mediated endocytosis is not a major internalization pathway for cobalt oxide particles. Internalization of cobalt oxide particles was markedly decreased in the presence of chlorpromazin, a cationic amphipathic drug used to probe clathrin-mediated endocytosis (Figure 5). Because of its amphipathic nature, chlorpromazine can readily be incorporated into the lipid bilayer of the plasma membrane. The resulting increase in lipid fluidity, which in turn inhibits or blocks the formation of membrane invaginations, leads to a strong decrease in cobalt oxide particle internalization. This inhibition was dose dependent (data not shown), and a high inhibition was achieved in the presence of $20 \mu \mathrm{g} . \mathrm{mL}^{-1}$ chlorpromazine (Figure 5). This experiment highlights the role of clathrin-mediated pathways for the internalization of cobalt oxide particles. Different mechanisms responsible for particle uptake are known to be activated, depending on particle size [35]. Xia et al. [36] previously showed on BEAS-2B cells that amino-modified polystyrene nanoparticle $(60 \mathrm{~nm})$ toxicity was dependent on caveolar uptake and could be reversed by methyl- $\beta$-cyclodextrin. In the present work, we identified clathrin-dependent endocytosis as the entry route for cobalt oxide particle internalization, in agreement with their larger size. 


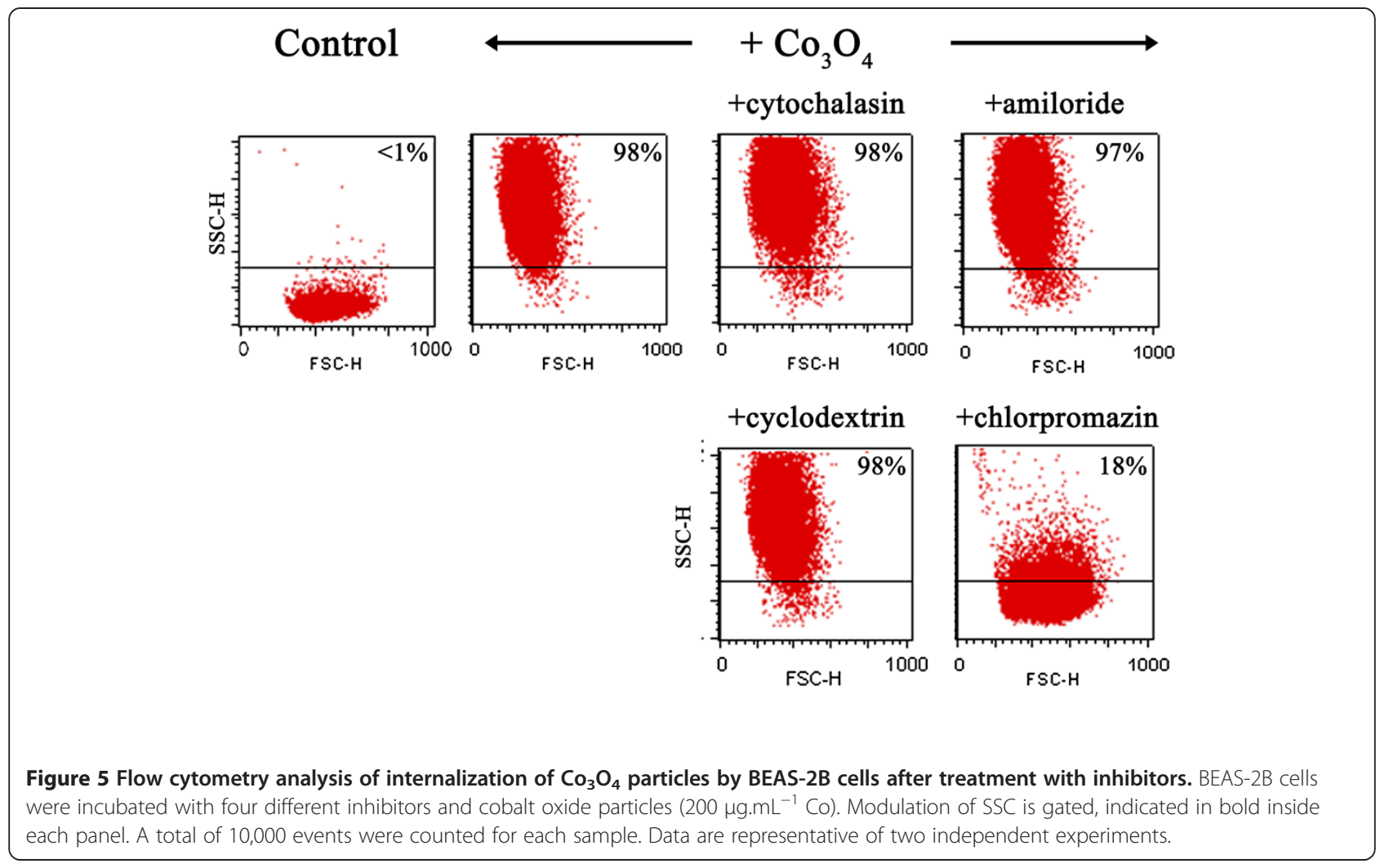

\section{Intracellular distribution of cobalt oxide particles}

Figure 6,A and B shows two representative TEM images of cells exposed for $1 \mathrm{~h}$ to $\mathrm{Co}_{3} \mathrm{O}_{4}\left(1 \mu \mathrm{g} \cdot \mathrm{mL}^{-1} \mathrm{Co}\right)$. Particle internalization as early as $1 \mathrm{~h}$ was clearly confirmed by this technique, as also indicated by SSC measurements (Figure 4, panel B). We noted that the quantity of cobalt oxide particles incorporated in the cells was within a wide range, some cells containing a few particles while others could accumulate dozens of them in the same sample. This distribution was also assessed through the wide SSC range given by flow cytometry (Figure 4, panel A). Particles were located in vacuoles which could be lysosomal (Figure 6C and D), and were not observed in the nucleus or dispersed in the cytoplasm. After $24 \mathrm{~h}$, the vacuoles containing particles were localized near the nucleus (Figure 6E). A focus on the cell membrane of cobalt oxide particles being internalized also suggests a clathrin-dependent endocytosis (Figure 6F).

In addition to TEM imaging, confocal microscopy was performed on BEAS-2B cells incubated for $24 \mathrm{~h}$ with $\mathrm{Co}_{3} \mathrm{O}_{4}$ particles $\left(20 \mu \mathrm{g} \mathrm{mL} \mathrm{m}^{-1} \mathrm{Co}\right)$ and labeled with organelle markers for the Golgi apparatus (GM130), early endosome (EEA1) and lysosome (LysoTracker Red), as shown in Figure 7. Cobalt oxide particles were clearly seen in reflection mode (green - false color) and DIC (differential interference contrast). Yellow staining in the merged images indicated a co-localization of cobalt oxide particles (green) only with the LysoTraker (red), confirming the lysosomal storage of $\mathrm{Co}_{3} \mathrm{O}_{4}$ particles in human lung BEAS-2B cells (Figure 7 panel $\mathrm{C}$ ).

The lysosome is the most common intracellular compartment for particles sequestration and degradation. The role of lysosomes in particles intracellular dissolution has been shown in the case of carcinogenic nickel particulate compounds, as recently reviewed [37], zinc oxide nanoparticles [32,38], and iron oxide microparticles [39]. The involvement of lysosomal intracellular dissolution in the release of free metal ions is also suggested in the case of platinum nanoparticles [40]. Our results demonstrate that $\mathrm{Co}_{3} \mathrm{O}_{4}$ particles are stored within the lysosomal compartment and solubilized in ALF, a medium simulating the lysosomal fluid. The lower $\mathrm{pH}$ and the action of hydrolytic enzymes within the lysosome may result in enhanced solubilization of cobalt oxide particles into free cobalt ions. Assessment of the intracellular dissolution of cobalt oxide particles was further carried out using two independent and complementary analytical techniques, as described in the next section.

\section{Intracellular solubilization of cobalt oxide particles}

An important key point was to measure the solubilized fraction of cobalt from the $\mathrm{Co}_{3} \mathrm{O}_{4}$ particles inside BEAS$2 \mathrm{~B}$ cells following exposure of the cells to $\mathrm{Co}_{3} \mathrm{O}_{4}$. This 

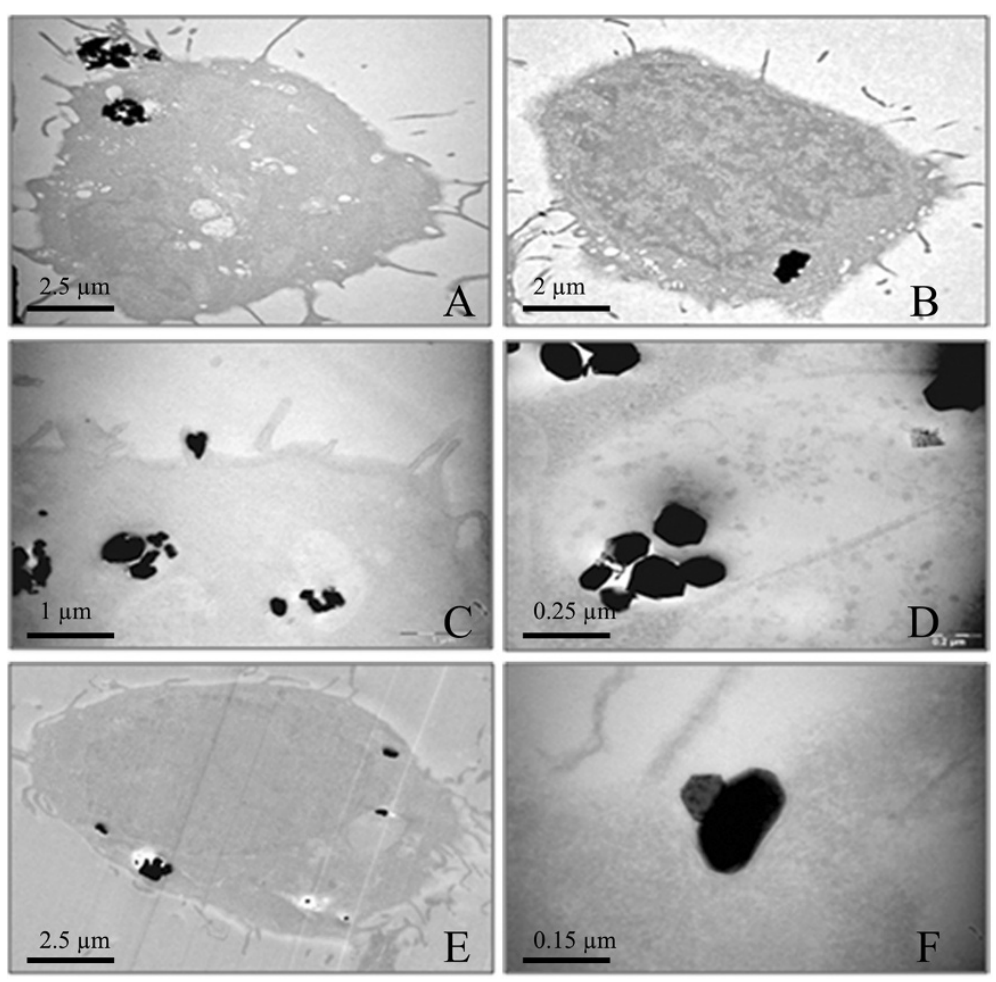

Figure 6 TEM images of BEAS-2B cells exposed to $\mathrm{Co}_{3} \mathrm{O}_{4}$ particles. BEAS2-B cells were exposed to $\mathrm{Co}_{3} \mathrm{O}_{4}$ particles at $1 \mu \mathrm{\mu g} \cdot \mathrm{mL}^{-1} \mathrm{Co}(\mathbf{A}$, $\mathbf{B}$, $\mathbf{F})$, $5 \mu \mathrm{g} \cdot \mathrm{mL}^{-1}$ Co (C) or $20 \mu \mathrm{g} \cdot \mathrm{mL}^{-1}$ Co (D, E) for $1 \mathrm{~h}(\mathbf{A}, \mathbf{B})$ or $24 \mathrm{~h}(\mathbf{C}, \mathbf{D}, \mathbf{E}, \mathbf{F})$.

information is crucial to try to determine a relationship between intracellular solubilized cobalt and toxicity. We used two analytical techniques, micro-PIXE (particle-induced X-ray emission) and ICP-MS, which have already shown their complementarity for intracellular cobalt content analysis in BEAS-2B and $\mathrm{HaCaT}$ cells [25,41]. PIXE analysis enabled to quantify the intracellular particulate fraction of Co which could not be achieved by ICP-MS. Indeed, during the cell harvesting, involving trypsinization and centrifugation, a fraction of extracellular cobalt oxide particles sediments together with the cells, preventing the accurate separation of intracellular particles from extracellular particles. ICP-MS analyses allowed only the measurement of the solubilized fraction of particles in the cell lysates.

Firstly, elemental analysis of intracellular solubilized cobalt content was performed by ICP-MS after lysis of cells exposed for $72 \mathrm{~h}$ in LHC9 to cobalt oxide particles, at IC25 and IC50 concentrations (50 and $170 \mu \mathrm{g} \cdot \mathrm{mL}^{-1}$ of Co), respectively. Table 2 shows that intracellular solubilization of cobalt particles occurred in a dosedependent manner, leading to 6.5 and $16.5 \mathrm{fg} /$ cell for IC25 and IC50 conditions, respectively. Cobalt oxide particle solubilization in culture medium after $72 \mathrm{~h}$ led to 0.11 and $0.29 \mu \mathrm{g} \cdot \mathrm{mL}^{-1}$ released cobalt (Table 2), for $\mathrm{Co}_{3} \mathrm{O}_{4}$ suspensions corresponding to IC25 and IC50. These very low amounts of extracellular solubilized cobalt in the culture medium after $72 \mathrm{~h}$ exposure to $\mathrm{Co}_{3} \mathrm{O}_{4}$ particles cannot be responsible for the observed toxicity, as demonstrated by cytotoxicity experiments (Figure 2).

To confirm these results, cells were also analyzed by micro-PIXE in order to quantify, in situ, the intracellular distribution of the particulate and solubilized fractions of cobalt, as shown in Figure 8, panel A. PIXE analysis is a valuable tool to quantify in situ insoluble materials in biological tissues which is usually difficult to perform using analytical techniques that require the prior solubilization of the samples [42]. When performed with a micro-focused beam, PIXE enables to distinguish within cells solid microparticles from the soubilized elemental fraction. Micro-PIXE is better suited to the investigation of microparticles rather than nanoparticles since its spatial resolution is between $200 \mathrm{~nm}$ and $800 \mathrm{~nm}$ depending on the analytical conditions. PIXE microanalysis offers a better detection sensitivity than TEM-EDX (about a factor of 100 ), which enables the direct quantification of the slightly solubilized fraction of cobalt in single cells. The chemical 

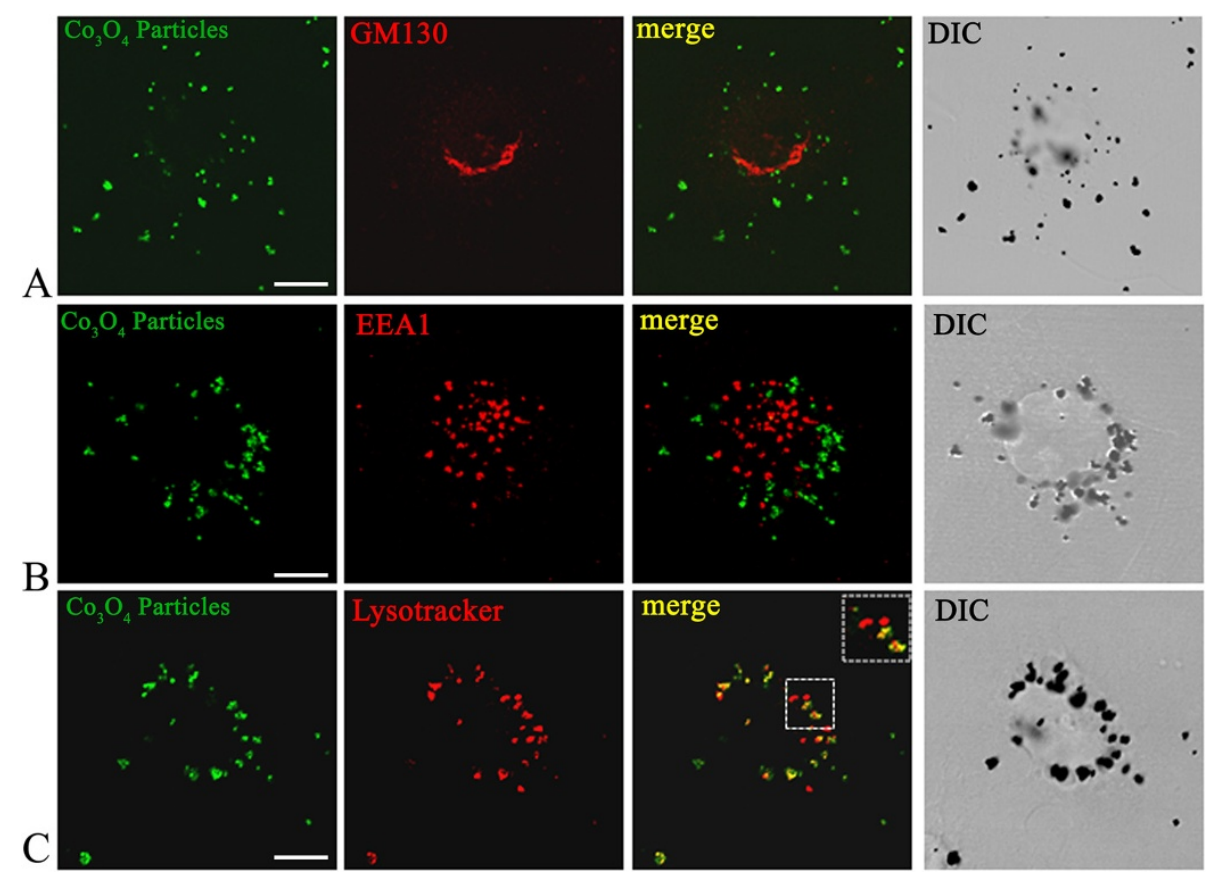

Figure 7 Confocal microscopy subcellular localization of $\mathrm{Co}_{3} \mathrm{O}_{4}$ particles. Cells were stained for Golgi marker GM130 (red) (A), early endosome marker EEA1 (red) (B), or lysosome marker LysoTracker (red) (C), as described in the materials and methods section, before being analyzed by confocal microscopy. Yellow staining in the merged images indicates co-localization of the cobalt oxide particles (green) with the fluorescent label (red). Scale bar, $10 \mu \mathrm{m}$.

map of potassium was used to delineate cell boundaries, as this element is ubiquitously distributed in cells. To determine the intracellular solubilized and particulate cobalt fractions, single cells were imaged and elemental quantification was carried out by PIXE microanalysis in whole cells, either excluding the particles (giving the solubilized fraction) or including only the cobalt oxide particles (giving the particulate fraction), as illustrated in Figure 8, panel B. The mean solubilized intracellular cobalt contents determined by PIXE were 6.7 and $48 \mathrm{fg} /$ cell after exposure to $\mathrm{Co}_{3} \mathrm{O}_{4}$ suspensions corresponding to IC25 and IC50 (Table 3), respectively, confirming the ICP-MS measurements of intracellular solubilized cobalt content after cell lysis.

The PIXE method enabled the determination, for the first time, of the intracellular solubilization ratio of metal oxide particles in single cells, even for a particularly low-solubility compound. Micro-PIXE chemical imaging confirmed that a small fraction of cobalt oxide particles was solubilized in cells. The solubilized cobalt fraction was detected within the cytoplasm and the nucleus of BEAS-2B cells (Figure 8 panel B and Table 4).

The quantitative micro-PIXE results of cobalt content and solubilization ratio in single BEAS-2B cells are presented in Table 3 . The solubilization ratio was $0.07 \%$ for cells exposed to $\mathrm{Co}_{3} \mathrm{O}_{4}$ suspensions corresponding to $50 \mu \mathrm{g} . \mathrm{mL}^{-1}$ cobalt (IC25), and $0.55 \%$ for cells exposed to $\mathrm{Co}_{3} \mathrm{O}_{4}$ suspensions corresponding to $170 \mu \mathrm{g} \cdot \mathrm{mL}^{-1}$ cobalt (IC50). No cobalt was measured in control cells (below the limit of detection of the micro-PIXE method). The solubilization ratios of the particles inside cells are lower than the solubilization ratios in artificial lysosomal fluid (around 2\% after $72 \mathrm{~h}$ ) (Figure 3 panel B), but higher than in culture medium at IC50 (0.21\%). A detailed examination of these results strongly suggests a role for lysosomal dissolution of cobalt oxide particles in cells. Endocytosis induces a delay in the lysosomal dissolution process within the cells, as compared with what occurs in a synthetic medium, such as ALF medium. Therefore, the length of intracellular exposure to an acidic $\mathrm{pH}$ in the lysosome is less than $72 \mathrm{~h}$. Even if cobalt oxide particle uptake begins early after exposure, the time to particle internalization can greatly vary from one cell to another, and can be as different as a few minutes to almost $72 \mathrm{~h}$. This is particularly emphasized for the IC50 condition, with a wide range of variability in the intracellular solubilization ratio, from $0.06 \%$ to $1.6 \%$. In this exposure condition, the extracellular cobalt solubilization ratio $(0.21 \%)$ is lower than the intracellular solubilization ratio $(0.55 \%)$, and in some cases this latter is as high as 

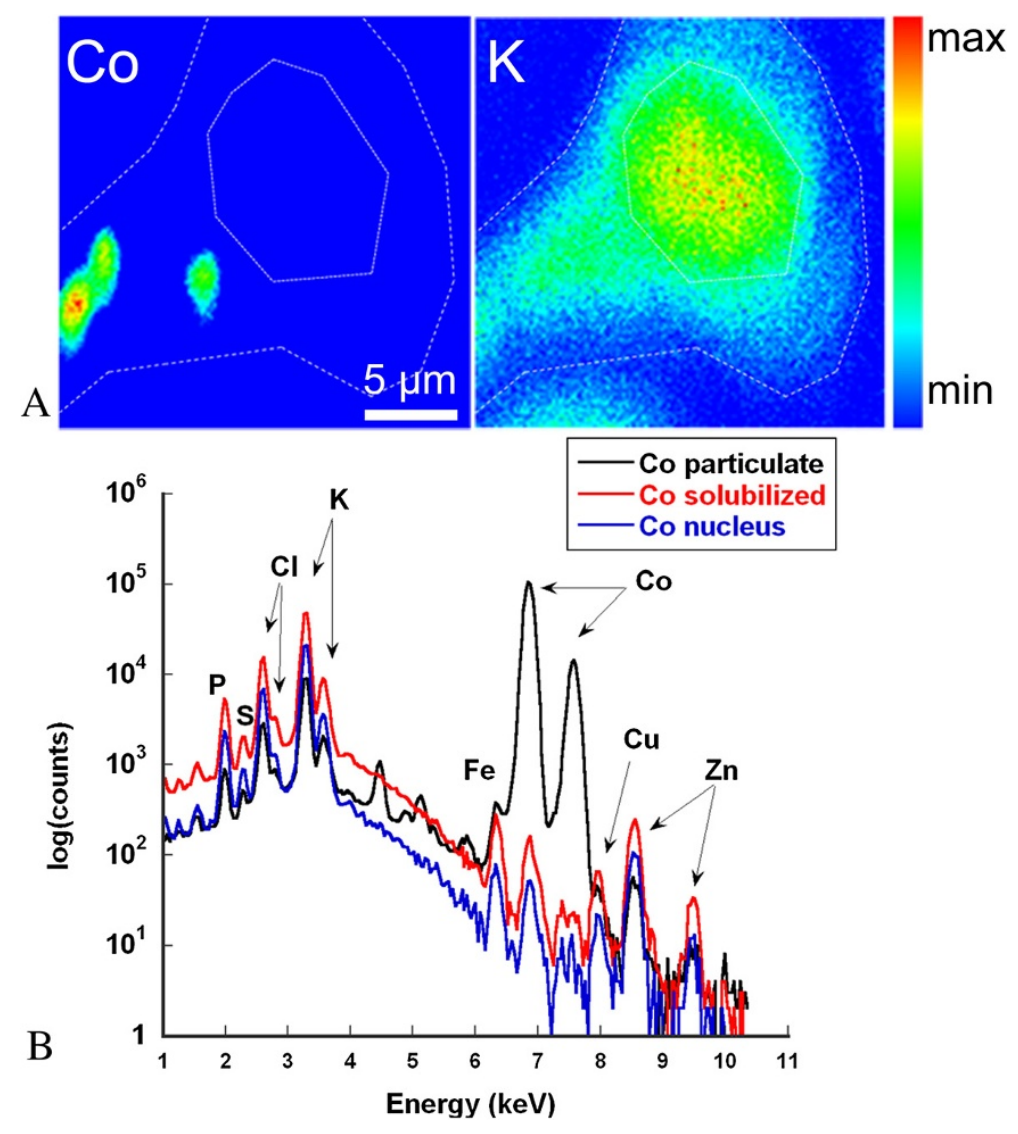

Figure 8 Example of micro-PIXE analysis of a single BEAS-2B cell exposed to cobalt oxide particles (50 $\left.\mu \mathrm{g} \cdot \mathrm{mL}^{-1} \mathrm{Co}\right)$ for $72 \mathrm{~h}$ (IC25). Potassium distribution delineates the cell boundaries and the nucleus position (A). The highest fraction of cobalt is found within the cytoplasm in its particulate form. A small fraction of cobalt is solubilized as shown by the local PIXE spectrum inside (particulate fraction) and outside (solubilized fraction) cobalt oxide particles (B). In this example, approximately $0.1 \%$ cobalt was solubilized and diffused into the rest of the cytoplasm and the nucleus.

Table 3 Intracellular cobalt solubilization assessed by single-cell quantitative imaging of cobalt (micro-PIXE) after exposure of BEAS-2B cells to $\mathrm{CO}_{3} \mathrm{O}_{4}$ particles for $72 \mathrm{~h}$

\begin{tabular}{|c|c|c|}
\hline $\begin{array}{c}\text { Co mean } \pm \text { SD } \\
(\mathrm{fg} / \text { cell })\end{array}$ & IC25 & IC50 \\
\hline \multirow[t]{2}{*}{ Particulate Co } & $9500 \pm 1650$ & $20,450 \pm 23,500$ \\
\hline & $\min 6593-\max 11,483$ & $\min 3062-\max 78,486$ \\
\hline \multirow[t]{2}{*}{ Solubilized Co } & $6.7 \pm 3.0$ & $48 \pm 20$ \\
\hline & $\min 3.4-\max 11.5$ & $\min 12.0-\max 70.0$ \\
\hline \multirow[t]{2}{*}{$\%$ solubilization } & $0.07 \pm 0.03$ & $0.55 \pm 0.50$ \\
\hline & $\min 0.04 \%-\max 0.12 \%$ & $\min 0.06 \%-\max 1.6 \%$ \\
\hline
\end{tabular}

$1.6 \%$, which can be explained by lysosomal dissolution at acidic $\mathrm{pH}$.

The intracellular solubilization of cobalt oxide particles was confirmed for the first time using two independent analytical approaches. Only a very small amount of cobalt was solubilized in BEAS-2B cells after $72 \mathrm{~h}$ exposure to

Table 4 Summary of the results obtained for the intracellular quantification and distribution of solubilized cobalt after exposure of BEAS-2B cells for $72 \mathrm{~h}$ to $\mathrm{Co}_{3} \mathrm{O}_{4}$ particles and soluble $\mathrm{CoCl}_{2}$ (both at IC25)

\begin{tabular}{ccc}
\hline $\begin{array}{c}\text { Analytical } \\
\text { technique }\end{array}$ & $\begin{array}{c}\text { Exposure } \\
\text { compound }\end{array}$ & $\begin{array}{c}\text { Intracellular solubilized Co } \\
\text { Mean } \pm \text { SD (fg/cell) }\end{array}$ \\
\hline PIXE & $\mathrm{CO}_{3} \mathrm{O}_{4}$ & $6.7 \pm 3.0$ \\
& & nucleus $: 3.3 \pm 2.0$ \\
cytoplasm: $3.4 \pm 1.5$ \\
ICP-MS & $\mathrm{Co}_{3} \mathrm{O}_{4}$ & $6.5 \pm 2.0$ \\
PIXE & $\mathrm{CoCl}_{2}$ & $5.4 \pm 0.8$ \\
\hline
\end{tabular}


cobalt oxide particles, which is in agreement with the known low solubility of this compound. The mean solubilized intracellular cobalt content determined by PIXE was $6.7 \mathrm{fg} /$ cell after exposure to $\mathrm{Co}_{3} \mathrm{O}_{4}$ suspensions corresponding to IC25, confirming the elemental ICP-MS measurements of intracellular solubilized cobalt content after lysis of cells, which was $6.5 \mathrm{fg} / \mathrm{cell}$ (Table 4). The quantitative analysis of solubilized cobalt content in the nucleus and the cytoplasm of BEAS-2B cells suggests a homogeneous distribution, in good agreement with our previous results obtained with cells exposed to soluble cobalt $\left(\mathrm{CoCl}_{2}\right)$ [25]. At IC50, PIXE and ICP-MS data are less in agreement with respective values of intracellular solubilized Co of 48 and $16.5 \mathrm{fg} / \mathrm{cell}$. Micro-PIXE measurements could be slightly overestimated due to the contribution of cobalt oxide particles especially as the number of particles incorporated within BEAS-2B cells is very high at IC50.

Another piece of evidence for cobalt oxide particle intracellular dissolution can be inferred from the study of cobalt-induced hypoxia due to the cellular effects of cobalt ions in solution. Cobalt ions are known as "hypoxia-simulating" agents [43]. We were able to observe a strong stabilization of the hypoxia-inducible factor 1 (HIF-1) by both cobalt forms, soluble cobalt chloride and particulate cobalt oxide (data not shown). A hypoxialike response induced by the particulate cobalt form could result from its partial solubilization in late endocytotic vesicles, a mechanism which has been described in macrophages from rabbits exposed to cobalt oxide particles of a similar size as those we studied [22]. As hypoxia seems to be an important mechanism in cobalt-induced lung inflammation [44], the fact that cobalt oxide can stabilize HIF-1, even if indirectly, is a key point when considering the mechanisms of toxicity of these particles.

\section{Impact of intracellular solubilization of cobalt oxide particles on toxicity}

The next major question is to determine if the toxicity induced by the particles is associated with the particles per se, with the intracellular solubilized cobalt fraction from the particles, or a combination of both. During the solubilization of cobalt oxide particles, Co(II,III) particles are reduced into solubilized $\mathrm{Co}(\mathrm{II})$, a reaction that can produce free radicals in cells. On the other hand, cobalt toxicity associated with soluble compounds has been documented by in vitro studies, mainly performed using cobalt chloride, $\mathrm{CoCl}_{2}$. These studies have shown that cobalt is genotoxic [45,46], induces oxidative stress [47], apoptosis [48], and is a hypoxia-simulating agent [49]. Micro-PIXE analysis was thus performed on BEAS-2B cells exposed to soluble cobalt chloride in similar toxicity conditions as those used for $\mathrm{Co}_{3} \mathrm{O}_{4}$ particles (IC25 and IC50 of Co, for $72 \mathrm{~h}$ ). It should be noted that, conversely to $\mathrm{Co}_{3} \mathrm{O}_{4}$ particles, cobalt chloride is present totally as soluble species in LHC9 medium [25]. Intracellular cobalt contents of, respectively, 5.4 and $9.6 \mathrm{fg} / \mathrm{cell}$ were found after exposure to $\mathrm{CoCl}_{2}$ at the IC25 and IC50 for $72 \mathrm{~h}\left(2.9\right.$ and $4.4 \mu \mathrm{g} \cdot \mathrm{mL}^{-1}$, respectively). It can be noted that the global total intracellular cobalt content is much higher after exposure of the cells to $\mathrm{Co}_{3} \mathrm{O}_{4}$ particles than to soluble $\mathrm{CoCl}_{2}$ (respectively, 9500 and $5.4 \mathrm{fg} / \mathrm{cell}$ at the IC25 of Co). This indicates that endocytosis is a very efficient uptake pathway in comparison with specific transport or ionic pumps that can be involved in soluble cobalt incorporation. The intracellular solubilized cobalt content after exposure to soluble $\mathrm{CoCl}_{2}$ was very close to those measured after exposure to cobalt oxide particles (Table 4). In addition, an increase in intracellular zinc content was measured by ICP-MS after lysis of the BEAS-2B cells exposed to $\mathrm{Co}_{3} \mathrm{O}_{4}$ particles for $72 \mathrm{~h}$ to the IC25 and IC50 of cobalt, from $57 \mathrm{fg} /$ cell in the control cells, to 103 and $135 \mathrm{fg} / \mathrm{cell}$, respectively (Table 2). In our previous work [25], a modulation of zinc homeostasis has been observed upon BEAS-2B exposure to the soluble cobalt compound, $\mathrm{CoCl}_{2}$. It is noticeable that exposure of BEAS2B cells to soluble cobalt and to particulate cobalt oxide induced a similar increase in intracellular zinc, reflecting a modulation of zinc homeostasis.

These results indicate two important mechanisms of toxicity: 1 ) the cobalt oxide particles are readily internalized by endocytosis via the clathrin-dependent pathway, then 2) they are partially solubilized within BEAS-2B cells and, even if the intracellular solubilized cobalt fraction is very low compared with the total cobalt content, this solubilized fraction is responsible for the overall toxicity. This latter aspect could be demonstrated as the intracellular solubilized cobalt content after exposure to $\mathrm{Co}_{3} \mathrm{O}_{4}$ particles $(6.5 \mathrm{fg} / \mathrm{cell})$ is similar to that after exposure to the soluble compound, $\mathrm{CoCl}_{2}(5.4 \mathrm{fg} / \mathrm{cell})$, for the same conditions of cytotoxicity (IC25). Such mechanisms have never been demonstrated for low-solubility particles such as cobalt oxide particles. Our results also explain the differences in cytotoxicity of more-soluble cobalt metal particles and poorly soluble cobalt oxide particles. Cobalt metal nanoparticles have been reported to induce cytotoxicity and oxidative stress to a greater extent than free cobalt ions $[6,8,9,29]$. In these studies, the associated cobalt particle toxicity was suspected to be due to the synergistic effect of cobalt released into the culture medium and/or after particle solubilization within the cells. The poorly soluble $\mathrm{Co}_{3} \mathrm{O}_{4}$ nanoparticles have been shown to be less toxic than free cobalt ions $[10,13]$, but caused rapid induction of ROS, with ROS levels higher than those induced by cobalt ions $[10,11]$. From these studies, it was suggested that the weak amount of extracellular solubilized cobalt in the culture medium could not be responsible for the observed toxicity, 
while toxicity due to the intracellular solubilization of $\mathrm{Co}_{3} \mathrm{O}_{4}$ nanoparticles following their internalization could not be excluded. However, to date no study has been reported that addresses the intracellular solubilization of cobalt from the $\mathrm{Co}_{3} \mathrm{O}_{4}$ particles, and the relationship with the toxicological effects. The use of high-sensitivity analytical techniques allowed us to demonstrate the relationship between the overall toxicity and the intracellular solubilization of cobalt from low-solubility cobalt oxide particles (Figure 9).

Our results on BEAS-2B cells, a non tumorigenic cellular model of airway epithelium, indicate that human bronchial epithelial cells exposed to $\mathrm{Co}_{3} \mathrm{O}_{4}$ microparticles are in fine exposed to a low concentration of solubilized $\mathrm{Co}$, and may be prone to health effects due to long term exposures to soluble Co. As soluble cobalt compounds such as $\mathrm{CoCl}_{2}$ are genotoxic and are classified as potential carcinogenic agents (classified by IARC as Group 2B), our results indicate that solubilized cobalt from $\mathrm{Co}_{3} \mathrm{O}_{4}$ particles could exert a genotoxic and carcinogenic effect. Genotoxic effects can be observed at very low concentrations without a threshold. In order to further elucidate cobalt oxide toxicity mechanisms, our next purpose will be to perform a comprehensive genotoxicity study (DNA breaks, chromosomal damage).

\section{Conclusion}

In conclusion, our study reveals for the first time that the overall toxicity of low-solubility metal oxide compounds such as $\mathrm{Co}_{3} \mathrm{O}_{4}$ cobalt oxide particles is due mainly, and perhaps totally, to their intracellular solubilization. This finding was made possible by the implementation of accurate and sensitive analytical techniques, based on single-cell chemical imaging and ICP-MS analysis of the solubilized cobalt fraction released from particles after cell lysis. Both techniques produced convergent results and highlighted the considerable contribution of analytical techniques to the understanding of complex mechanisms of toxicity of particulate compounds. We also showed that cobalt oxide particles were rapidly taken up by BEAS-2B cells, clathrin-mediated endocytosis probably being the main pathway for internalization of these particles. Cobalt oxide particles were located within the lysosome, where the acidic $\mathrm{pH}$ and hydrolytic enzymes enhance their solubilization. Our results, and studies from other research groups $[7,15,16,31]$, confirm the importance of intracellular particle solubilization-associated mechanisms of toxicity. Our results apply to the BEAS-2B cell line, they should now be confirmed with other lung cell models to take into account the 'cell vision effect' [50]. In addition, cobalt oxide particles are cleared slowly from the lung and can remain in pulmonary cells for several months or years [3,18-21], thus representing a source of internal solubilized cobalt exposure. We have also shown that cobalt oxide particles would produce significant toxic effects only at very high concentrations, which are not relevant to environmental or even accidental occupational exposures.

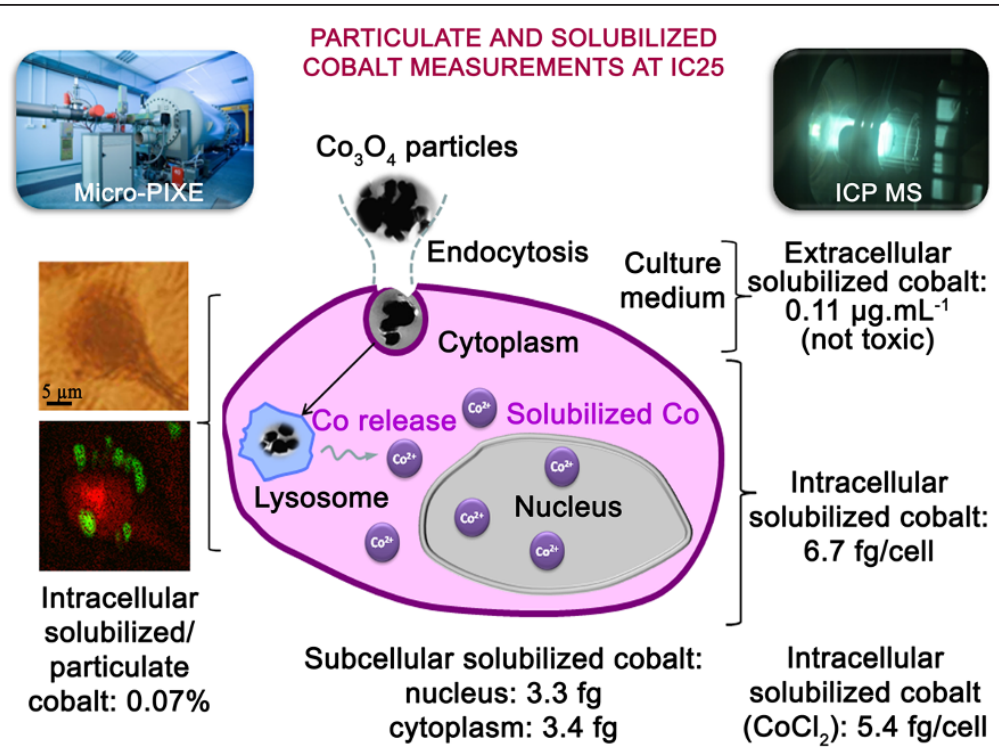

Figure 9 Schematic overview of the experimental design and of the main results for particulate and solubilized cobalt quantitative analysis at IC25. 


\section{Methods \\ Reagents}

LHC9, LHC basal medium and trypsin were purchased from Life Technologies. $\mathrm{Co}_{3} \mathrm{O}_{4}$ particles were supplied by Merck. The manufacturer's quality control sheet indicated a purity of $98.4 \% . \mathrm{Co}_{3} \mathrm{O}_{4}$ stock solutions $(10 \mathrm{mg}$. $\mathrm{mL}^{-1}$ cobalt in MilliQ $\mathrm{H}_{2} \mathrm{O}$ ) were sonicated for $15 \mathrm{~min}$ with an Autotune sonicator (Fisher Scientific) operated at $750 \mathrm{~W}$, and then stored at $-20^{\circ} \mathrm{C}[26] . \mathrm{CoCl}_{2} \cdot 6 \mathrm{H}_{2} \mathrm{O}$ was purchased from Sigma and prepared similarly without the sonication step. Stock solutions were diluted in culture medium and sonicated for $15 \mathrm{~min}\left(\mathrm{Co}_{3} \mathrm{O}_{4}\right)$ or $1 \mathrm{~min}$ (LB-3) before further dilution and addition to cell culture plates. Nitric and hydrochloric acid of high purity grade $\left(\mathrm{HNO}_{3} 65 \%\right.$ Normapur and $\mathrm{HCl} 35 \%$ Rectapur $)$ were purchased from VWR Prolabo (France) and PBS from Gibco BRL. Cobalt solutions for the ICP AES/MS calibration curves were prepared from standard solutions $\left(1000 \mu \mathrm{g} \cdot \mathrm{mL}^{-1}\right)$, which were purchased from SPEX (SPEX Certiprep Company). Negative controls were performed with Latex Beads (LB-3, Sigma) of size close to those of the $\mathrm{Co}_{3} \mathrm{O}_{4}$ particles. RIPA lysis buffer was purchased from Santa Cruz and Mini EDTA-free protease inhibitor cocktail from Roche. The CellTiterGlo Luminescence Cell Viability Assay was purchased from Promega. PALL Acrodisc filters $(0.1 \mu \mathrm{m})$ were purchased from VWR. Other reagents were purchased from Sigma.

\section{Cobalt oxide particle characterization}

Particle size distribution was assessed by dynamic light scattering (DLS) measurements of particle suspensions using a Nano ZS ZetaSizer (Malvern). Each suspension was vigorously shaken prior to analysis. We assessed the effects of a more drastic physical dispersion method on particle size distribution. For this, the samples were sonicated with an Autotune $750 \mathrm{~W}$ ultrasonicator (Fisher Scientific) with the microprobe set at $40 \%$ power. Sonication was performed on melting ice to avoid sample heating. Particle suspensions were then poured into clean disposable cuvettes. At least three independent DLS runs were performed at $25^{\circ} \mathrm{C}$, with each consisting of the average of fifteen consecutive measurements.

\section{Cell cultures and exposure to cobalt oxide particles}

The BEAS-2B human bronchial epithelial cell line was obtained from the American Type Culture Collection (CRL\#9609). BEAS-2B cells are transformed human bronchial epithelial cells. They have been extensively used for particle toxicity studies, including the assessment of cellular uptake routes and the study of cellular stress response [32,36].

Cells were cultured in LHC9 medium in flasks or in precoated plates. The coating was performed using a mixture of BSA $\left(0.01 \mathrm{mg} \cdot \mathrm{mL}^{-1}\right)$, human fibronectin (0.01 mg.mL $\left.\mathrm{m}^{-1}\right)$ and collagen $\left(0.03 \mathrm{mg} \cdot \mathrm{mL}^{-1}\right)$ prepared in LHC basal medium. All cell cultures were maintained in $75 \mathrm{~cm}^{2}$ cell culture flasks at $37^{\circ} \mathrm{C}$ in $5 \% \mathrm{CO}_{2}$ at $95 \%$ humidity. The cells were passaged by trypsinization $(0.25 \%$ tryp$\sin / 2.6 \mathrm{mM}$ EDTA) at 70-80\% confluency every 3-4 days.

Normal primary human bronchial epithelial cells (NHBE) were obtained from Clonetics ${ }^{\text {Tm }}$ (Lonza, Switzerland). Cells were maintained in bronchial epithelial basal medium (BEBM) (Lonza, Walkersville, MD) supplemented with growth factors from the SingleQuots kit (as recommended by the manufacturer; Lonza, Walkersville, MD) to make BEGM, which contains a retinoic acid (RA) supplement. All cell cultures were maintained in $75 \mathrm{~cm}^{2}$ cell culture flasks at $37^{\circ} \mathrm{C}$ in $5 \% \mathrm{CO}_{2}$ at $95 \%$ humidity. The culture medium was changed every $48 \mathrm{~h}$ until the cells reached $70-80 \%$ confluency; cells were then passaged by trypsinization (trypsin neutralizing solution).

For $\mathrm{Co}_{3} \mathrm{O}_{4}$ exposure experiments, cells were seeded at 10,000 cells $/ \mathrm{cm}^{2}$. The LHC9 medium was replaced $24 \mathrm{~h}$ later with cobalt-containing medium and cells were incubated for $72 \mathrm{~h}$, except for the clonogenic assay. Exposure solutions $\left(0-1000 \mu \mathrm{g} \cdot \mathrm{mL}^{-1} \mathrm{Co}\right)$ were freshly prepared by diluting the appropriate volume of stock solution in culture medium, and sonicated for $15 \mathrm{~min}$ as described above, prior to addition to cell culture plates. As exposure was performed in 6- or 96-well plates, or in $175 \mathrm{~cm}^{2}$ flasks, the volume of exposure solution was strictly adjusted to the surface of the well or flask. This precaution is mandatory to obtain a perfect correspondence between concentrations expressed either in $\mu \mathrm{g} \cdot \mathrm{mL}^{-1}$ or in $\mu \mathrm{g} / \mathrm{cm}^{2}$. A concentration of $100 \mu \mathrm{g} \cdot \mathrm{mL}^{-1}$ corresponded to $33 \mu \mathrm{g} / \mathrm{cm}^{2}$.

\section{Cell toxicity assays}

The effects of $\mathrm{Co}_{3} \mathrm{O}_{4}$ particles, $\mathrm{CoCl}_{2}$, and latex beads (LB-3) on the viability of human BEAS-2B cells were evaluated using two methods: the CellTiter-Glo assay and the Clonogenic assay.

First, cell viability was measured using the Promega CellTiter-Glo $^{\text {Tw }}$ Luminescence Cell Viability Assay. This test allows the measurement of the amount of intracellular ATP, this metabolite being directly linked to the number of metabolically active cells. For this, cells were plated at 10,000 cells $/ \mathrm{cm}^{2}$ in white 96 -well plates and grown for $24 \mathrm{~h}$. The medium was replaced with $\mathrm{Co}_{3} \mathrm{O}_{4}$, $\mathrm{CoCl}_{2}$, or LB-3 solutions and the plates were incubated for a further $72 \mathrm{~h}$ period. The protocol described by the manufacturer was modified to avoid particle interference during luminescence reading [26]. The Promega CellTiterGlo reagent $(100 \mu \mathrm{L})$ was added, and after 20 min incubation plates were centrifuged (900 g, $5 \mathrm{~min}$ ) to pellet the $\mathrm{Co}_{3} \mathrm{O}_{4}$ particles. $100 \mu \mathrm{L}$ supernatant from each well was transferred into an empty plate. These conditions for 
$\mathrm{Co}_{3} \mathrm{O}_{4}$ particle removal were shown to allow full recovery of the signal. The luminescence was measured on a plate reader (LumiStar, BMG). For each condition, a minimum of three independent assays were carried out, each being performed in quadruplicate. In order to have the highest signal, the gain was adjusted to $90 \%$ of the maximum read signal, and a $5 \mathrm{~s}$ integration reading was used. Variability among experiments was taken into account, and all values were expressed in\% (mean luminescence for a sample divided by the mean luminescence for unexposed cells $\mathrm{X}$ 100). Data were analyzed using the Prism 4 v4.0 software (GraphPad software). The half-maximal inhibitory concentration (IC50), was calculated as the half-maximal (50\%) inhibitory concentration (IC) of cobalt. The IC25 and IC75 were also determined.

We also performed the clonogenic assay described by Puck and Markus [51] and Franken et al. [52]. Exponentially growing cells (BEAS-2B and NHBE) were harvested and seeded in 6-well microplates (Nunc, Denmark) at a density of 200 cells/well in $3 \mathrm{~mL}$ cell culture medium. Cells were allowed to attach for approximately $16 \mathrm{~h}$, a time shorter than the population-doubling time of the cell line, which is reported to be around $24 \mathrm{~h}$. The medium was then replaced with $\mathrm{Co}_{3} \mathrm{O}_{4}\left(0-1000 \mu \mathrm{g} \cdot \mathrm{mL}^{-1} \mathrm{Co}\right)$ or LB-3 $\left(0-1000 \mu \mathrm{g} \cdot \mathrm{mL}^{-1}\right)$ solutions and the plates were incubated for a further $24 \mathrm{~h}$ period. After $24 \mathrm{~h}$ exposure, the medium was replaced with fresh culture medium. This medium renewal was performed twice per week. BEAS-2B and NHBE cells were cultured over 10 days corresponding to the time needed to obtain colonies, a colony being defined as at least 50 clones of one initial cell. The colonies were stained with crystal violet $(0.5 \%)$ for $30 \mathrm{~min}$ and rinsed with water. Viable colonies containing more than 50 cells were counted manually. The results were normalized with the unexposed control and expressed as colony forming efficiency, which is the ratio of the mean number of colonies in the treated condition over the mean number of colonies in the control condition. Data were analyzed using the Prism 4 v4.0 software (GraphPad software). The half-maximal inhibitory concentration (IC50) was calculated as the half-maximal (50\%) inhibitory concentration (IC) of cobalt.

\section{Solubilization ratio measurement of $\mathrm{Co}_{3} \mathrm{O}_{4}$ particles in culture media}

Elemental analyses were performed with an Activa ICPAES spectrometer (Jobin Yvon) or an XSeries ${ }^{\mathrm{II}}$ ICP-MS (ThermoElectron). For ICP-AES analyses, an external standard calibration curve using three wavelength emission lines at 228.616, 237.862, and $238.892 \mathrm{~nm}$, with $5 \mathrm{~s}$ integration time, was used. For each wavelength, data were the mean value of five replicates and the final concentration was the mean value obtained for the three wavelengths. For ICP-MS analyses, an external standard calibration curve was used by monitoring ${ }^{59} \mathrm{Co}$ isotope combined with Indium internal calibration; data were the mean value of ten replicates.

The reference medium for BEAS-2B cells used in this study is LHC9 (pH 7.4), which is widely used for the culture of primary human lung cells. This medium comprises basal medium (LHCB), which mainly contains salts and amino acids supplemented with proteins and growth factors (retinoic acid, insulin, epidermal growth factor, bovine pituitary extract, hydrocortisone, and triiodothyronin) but does not contain fetal calf serum.

Three independent sets of $\mathrm{Co}_{3} \mathrm{O}_{4}$ particle suspensions (50, 170, and $600 \mu \mathrm{g} \cdot \mathrm{mL}^{-1}$ cobalt) were prepared in the appropriate volume of LHC9 and were equilibrated respectively for 3 and 7 days at $37^{\circ} \mathrm{C}$. The total cobalt concentration in each sample was measured by ICP-AES or ICP-MS. The samples were evaporated to dryness and digested consecutively in ultrapure $\mathrm{HCl}$ and $\mathrm{HNO}_{3}$, which were also evaporated to dryness. The residue was further resolubilized in $1 \mathrm{~mol} . \mathrm{L}^{-1} \mathrm{HNO}_{3}$ for elemental analysis. The solubilized fraction of cobalt from the $\mathrm{Co}_{3} \mathrm{O}_{4}$ particles was also measured from three independent sets. The particle suspensions $(50,170$, and $600 \mu \mathrm{g}$. $\mathrm{mL}^{-1}$ cobalt) were equilibrated for 3 and 7 days at $37^{\circ} \mathrm{C}$, and further centrifuged for $1 \mathrm{~h}$ at $160,000 \mathrm{~g}$ in order to separate the cobalt particles from the solubilized cobalt fraction kept in the supernatants, which were filtered through a $0.1 \mu \mathrm{m}$ membrane filter. The absence of particles in the supernatant was verified by DLS. The supernatants were further treated as described above and the cobalt concentration was measured by ICP-MS in each of them. The ratio of solubilized cobalt fraction over the total cobalt content, expressed in percentage, allowed reaching the dissolution ratio of the cobalt oxide particles. Similar measurements were performed in ALF medium ( $\mathrm{pH} 4.5$ ), prepared according to the method of Marques et al. [53]. Data are reported as the means with the relative combined uncertainty, taking into account the uncertainty associated with the total cobalt concentration $(3 \%$ at $\mathrm{k}=2)$ and the Co concentration in the supernatants $\left(3 \%\right.$ and $7 \%$ at $\mathrm{k}=2$ for concentrations $>0.05 \mu \mathrm{g} \cdot \mathrm{mL}^{-1}$ and $<0.05 \mu \mathrm{g} \cdot \mathrm{mL}^{-1}$, respectively).

\section{Cobalt oxide particle uptake by BEAS-2B cells}

Cellular uptake of particles can be directly assessed by measuring the increase in scattering (side scatter or $\mathrm{SSC}$ ) of the laser light in a flow cytometer $[54,55]$. It has previously been shown that cell fluorescence after phagocytosis of fluorescent latex beads increases in the same manner as the mean SSC of the cells [55]. BEAS-2B cells were treated with cobalt particles at $200 \mu \mathrm{g} \cdot \mathrm{mL}^{-1}$ Co during different periods ( 0.5 to $5 \mathrm{~h}$ ). After specific treatment times, the cells were trypsinized, centrifuged, and washed in PBS. Cell suspensions were analyzed using a 
FACSCalibur flow cytometer (Beckton Dickinson) with the following parameters: excitation at $\lambda_{\text {ex }} 488 \mathrm{~nm}$ and detection at $\lambda_{\mathrm{em}} 530 \pm 15 \mathrm{~nm}$. Right-angle light scatter or side scatter (SSC) was measured through a BP $488 \mathrm{~nm}$ filter positioned at $90^{\circ}$ incident to the cell flow, while fluorescence emission from latex particles was recorded with a BP $520 \mathrm{~nm}$ filter. Particle uptake was monitored using the Stringer et al. method [54]. Because ingested or bound particles induce a more granular morphology of the epithelial cells, the laser light is scattered to a greater extent by these cells. Thus, the SSC signal is directly correlated to the quantity of particles bound or ingested. Particle uptake was monitored with the increased SSC signal from a univariate histogram of SSC versus the number of events (after selection of viable cells by gating from a bivariate histogram of forward-angle light scatter versus SSC). As unbound particles were substantially smaller than epithelial cells, they were removed from the forward-angle light scatter versus SSC window by adjusting the electronic threshold settings. Series of 10,000 events were counted for each condition. Data were processed using Beckton Dickinson CellQuest software.

BEAS-2B cells were treated with either $5 \mu \mathrm{g} \cdot \mathrm{mL}^{-1}$ cytochalasin $\mathrm{B}, 50 \mu \mathrm{M}$ amiloride, 0.5 or $5 \mathrm{mM}$ methyl- $\beta$ cyclodextrin, or 2,10 or $20 \mu \mathrm{g} \cdot \mathrm{mL}^{-1}$ chlorpromazine. Cells were preincubated in LHC9 medium containing these drugs at a $2 \mathrm{X}$ concentration for $1 \mathrm{~h}$ at $37^{\circ} \mathrm{C}$ and $5 \% \mathrm{CO}_{2}$. Cobalt oxide particles were then added to the cells in an equal volume of medium $\left(200 \mu \mathrm{g} \cdot \mathrm{mL}^{-1} \mathrm{Co}\right)$, and further incubated for $5 \mathrm{~h}$ at $37^{\circ} \mathrm{C}$ and $5 \% \mathrm{CO}_{2}$. After exposure to particles and inhibitors, the cells were washed with PBS, trypsinized, and processed for flow cytometry as described above. Drug concentrations were chosen according to previous work $[56,57]$.

\section{Transmission electron microscopy (TEM)}

BEAS-2B cells were exposed to $\mathrm{Co}_{3} \mathrm{O}_{4}$ particle suspensions $\left(1,5\right.$, and $\left.20 \mu \mathrm{g} \cdot \mathrm{mL}^{-1} \mathrm{Co}\right)$ for $1 \mathrm{~h}$ and $24 \mathrm{~h}$. These low concentrations were chosen to allow the cutting of ultrathin sections, as cobalt oxide is a very hard material which damages the cutting device as well as the cell layer. After exposure, the medium was removed and the cell layer was washed with PBS. Cells were then fixed with $2.5 \%$ glutaraldehyde in $0.1 \mathrm{M}$ sodium cacodylate buffer ( $\mathrm{pH}$ 7.4) for $4 \mathrm{~h}$ at room temperature. After fixation, cells were washed three times for $5 \mathrm{~min}$ in the sodium cacodylate buffer. Samples were post-fixed with $1 \%$ osmium tetroxide in same buffer for $1 \mathrm{~h}$, dehydrated through a graded ethanol series, and finally embedded in Epon 812. All chemicals used for histological preparation were purchased from Electron Microscopy Sciences (Hatfield, USA). Ultrathin $120 \mathrm{~nm}$ sections were obtained using an UCT ultramicrotome (Leica,
Microsystems GmbH, Wetzlar, Germany) mounted on copper grids, and examined in a Tecnai $12 \mathrm{G}^{2}$ Biotwin scanning transmission electron microscope (FEI Company, Eindhoven, the Netherlands) coupled with a Megaview III CCD camera (Olympus Soft imaging Solutions $\mathrm{GmbH}$, Münster, Germany). At least 50 photographs of detailed local structures of cells were taken, analyzed and compared for each condition. Several cobalt particles were detected and focused with a Phoenix energy dispersive X-ray microanalyser (EDAX Inc., Mahwah, USA) equipped with a Sapphire Super Ultra Thin window detector.

\section{Confocal microscopy}

BEAS-2B cells were grown on glass coverslips. They were incubated with $\mathrm{Co}_{3} \mathrm{O}_{4}$ particles $\left(20 \mu \mathrm{g} \cdot \mathrm{mL}^{-1} \mathrm{Co}\right)$ for $24 \mathrm{~h}$ at $37^{\circ} \mathrm{C}$. After three washes in phosphate buffered saline (PBS), cells were fixed for $15 \mathrm{~min}$ with $4 \%$ paraformaldehyde and neutralized with $10 \mathrm{mM} \mathrm{NH}_{4} \mathrm{Cl}_{2}$ in PBS for $15 \mathrm{~min}$. After three washes in PBS, cells were permeabilized with PBS containing 0.1\% Triton X-100 and $0.5 \%$ bovine serum albumin. To detect endogenous proteins, coverslips were incubated with the following primary antibodies: monoclonal mouse anti-EEA1 for early endosomes (BD Biosciences, Palo Alto, CA, USA; used at 1:50) and monoclonal mouse anti-GM130 for golgi apparatus (BD Biosciences, Palo Alto, CA, USA; used at 1:200). After three washes with PBS, the coverslips were incubated with FluoProbes ${ }^{\oplus} 54$ fluorochromecoupled secondary anti-species antibodies (Interchim, Montluçon, France; used at 1:400). For lysosome staining, cells were incubated before fixation with $100 \mathrm{nM}$ LysoTracker Red DND-99 (Molecular Probes) at $37^{\circ} \mathrm{C}$ for $1 \mathrm{~h}$. Cells were washed and the coverslips were mounted on slides using Mowiol 4-88 as antifading agent in a glycerol-based mounting medium. Confocal imaging was performed using a Leica TCS SP2 confocal microscope with a $63 \mathrm{X}$ oil immersion objective, by sequential excitation at $488 \mathrm{~nm}$ and $543 \mathrm{~nm}$, at the Bordeaux Imaging Center Ibisa platform (www.bic. u-bordeaux2.fr). $\mathrm{Co}_{3} \mathrm{O}_{4}$ particles were detected by reflection mode at $488 \mathrm{~nm}$. Adobe Photoshop software (Adobe Systems, San Jose, CA) was used for image processing.

\section{ICP-MS analysis of intracellular solubilized cobalt and zinc content}

Elemental analyses of cobalt and zinc in BEAS-2B cell lysates were performed by ICP-MS after cells exposure to several $\mathrm{Co}_{3} \mathrm{O}_{4}$ particle suspensions for $72 \mathrm{~h}$. After exposure of the cells to 0 , IC25 and IC50 respectively $\left(0,50\right.$ and $170 \mu \mathrm{g} . \mathrm{mL}^{-1}$ of cobalt) for $72 \mathrm{~h}$, cells contained in the flasks were harvested, washed, counted using the trypan blue exclusion method on an automated cell counting system Cedex (Roche Innovatis), and further submitted to lysis. Hence for each experiment, the cobalt 
content was measured within a known number of cells, rendering possible the normalization. Data were collected from two independent experiments, each performed in duplicate. LHC9 alone was used for the control. Cells were plated at 10,000 cells $/ \mathrm{cm}^{2}$ in $175 \mathrm{~cm}^{2}$ precoated flasks and were allowed to attach for approximately $16 \mathrm{~h}$. The medium was replaced with suspensions of $\mathrm{Co}_{3} \mathrm{O}_{4}$ particles prepared in LHC9 medium, corresponding to 0, IC25 and IC50 $\left(0,50\right.$ and $\left.170 \mu \mathrm{g} \cdot \mathrm{mL}^{-1}\right)$ cobalt, respectively. After incubation for a further $72 \mathrm{~h}$ period, the medium was removed, the cells were carefully rinsed with PBS and detached with trypsin. The cells were lysed with $2 \mathrm{~mL}$ RIPA lysis buffer containing protease inhibitor cocktail tablet (one tablet for $10 \mathrm{~mL}$ lysis buffer). The cellular extracts were sonicated five times for $5 \mathrm{~s}$, incubated on ice for $30 \mathrm{~min}$, and centrifuged at $160,000 \mathrm{~g}$ for $60 \mathrm{~min}$ at $4^{\circ} \mathrm{C}$. The supernatants were carefully filtered through a $0.1 \mu \mathrm{m}$ membrane filter for further analysis. Supernatants were successively digested with ultrapure $\mathrm{HCl}$ and ultrapure $\mathrm{HNO}_{3}$. Acids were evaporated to dryness and the residue digested again in $\mathrm{HNO}_{3} / \mathrm{HCl}$ mixture, in which it was further analyzed. Intracellular solubilized cobalt and zinc content were expressed as $\mathrm{fg} / \mathrm{cell}$. In each case, data were the mean values of four experiments, with relative combined uncertainties taking into account the uncertainties related to the standards preparation, the concentration measurement in exposure solutions ( $3 \%$ for cobalt at $\mathrm{k}=2$ and $10 \%$ for zinc at $k=2$ ), the intracellular amount determined by ICP-MS $(10 \%$ at $\mathrm{k}=2)$ and the cell count $(25 \%$ at $\mathrm{k}=2)$. For all experiments, cobalt and zinc concentrations were measured experimentally in the exposure solutions and the zinc concentration was found to be in agreement with the expected concentration in LHC9 [58].

\section{PIXE microanalysis}

Cells were grown on polycarbonate foils and exposed for $24 \mathrm{~h}$ to $\mathrm{Co}_{3} \mathrm{O}_{4}$ particles at cobalt concentrations of 0,50 and $170 \mu \mathrm{g} . \mathrm{mL}^{-1}$ (CTRL, IC25, IC50). Cells were cryofixed and freeze-dried to preserve both the chemical and morphological distributions, according to established protocols [59]. Ion-beam quantitative imaging using PIXE and RBS (Rutherford Backscattering Spectrometry) were performed simultaneously with a proton beam of 3.0 $\mathrm{MeV}$ energy on the nano-beamline of the AIFIRA facility (Applications Interdisciplinaires des Faisceaux d'Ions en Région Aquitaine) at CENBG (Centre d'Etudes Nucléaires de Bordeaux Gradignan). The proton beam is provided by a 3.5 MV single stage electrostatic accelerator designed by the High Voltage Engineering Europa B.V. company (Singletron). PIXE is a well established analytical technique for the quantitative determination of the elements in various types of materials, including biological samples [60]. The detailed protocols for accurate quantitative element analysis in biological samples used in our study have been described by Carmona et al. [59] and are based on previous works using the combination of PIXE and RBS analyses [61]. RBS is performed in complement to PIXE to determine the matrix composition, $\mathrm{C}, \mathrm{N}$, and $\mathrm{O}$ in the case of biological samples. PIXE analysis enables the detection of trace elements of $\mathrm{Z}>11$ with a detection limit of about 1 to $10 \mu \mathrm{g} / \mathrm{g}$, whereas RBS analysis is carried out to determine the sample mass and incoming charge. The combination of both methods results in fully quantitative analysis: trace element content normalized by the local mass of the sample [59]. The proton beam was focused down to a $0.8 \mu \mathrm{m}$ spot size, resulting in a $350 \mathrm{pA}$ beam current on target, for the analysis of single cells to determine in situ the trace element content ( $\mathrm{Mg}, \mathrm{P}, \mathrm{S}, \mathrm{K}, \mathrm{Ca}, \mathrm{Fe}, \mathrm{Co}$ and $\mathrm{Zn}$ ) in subcellular compartments (nucleus, cytoplasm). The square scanning side size typically ranged from 20 to $50 \mu \mathrm{m}$ with $128 \times 128$ pixel resolution. X-ray analyses were performed in a two-Si $(\mathrm{Li})$ detector configuration (e2v Scientific Instruments, Sirius $80 \mathrm{~mm}^{2} / \mathrm{Be} / \mathrm{PIXE}$ (CENBG custom) and RBS with a Si detector (PIPS, PD series, $25 \mathrm{~mm}^{2}$, Canberra). RBS and PIXE raw data were converted with a Labview data converter routine (CENBG homemade) and analyzed with SIMNRA [62] and GUPIXWIN [63] softwares.

\section{Competing interests}

The authors declare that they have no competing interests.

\section{Authors' contributions}

$\mathrm{RO}, \mathrm{CB}$ and $\mathrm{VM}$ participated in the experiments and drafted the manuscript. $C D, V A, M F, C G, S R$, LP and MJ carried out the experiments, analyzed the data and revised the manuscript. $\mathrm{VM}, \mathrm{RO}, \mathrm{CB}, \mathrm{AC}$ designed the study, analyzed the data, and revised the manuscript. All authors read and approved the final manuscript.

\section{Acknowledgements}

The authors would like to acknowledge the transversal toxicology program from the CEA DSV (France) and Electricité De France (EDF) company for their financial support and are grateful to CENBG staff, particularly to Guillaume Devès and Stéphanie Sorieul, for their technical support on ion beam microanalysis. We thank two undergraduate students, Pauline Guéraud and Wendeline Naudin, for their enthusiastic technical support during their practical training. We also thank our colleagues, Eric Ansoborlo (CEA-Marcoule, DEN/DRCP) and Nicole Sage (CEA-Marcoule, DEN/DTEC) for helpful discussions and technical support, respectively.

\section{Author details}

'Univ. Bordeaux, CENBG, UMR 5797, Gradignan F-33170, France. ${ }^{2}$ CNRS, IN2P3, CENBG, UMR 5797, Gradignan F-33170, France. ${ }^{3}$ CEA, DEN, DPC, SEARS, Laboratoire de développement Analytique Nucléaire, Isotopique et Elémentaire, Gif-sur-Yvette F-91191, France. ${ }^{4}$ CEA, DSV, IBEB, Lab Biochim System Perturb, Bagnols-sur-Cèze F-30207, France. ${ }^{5}$ CEA, DEN, DPC, SEARS, Laboratoire d'Analyse en Soutien aux Exploitants, Gif-sur-Yvette F-91191, France. ${ }^{6}$ IRSN, Institut de Radioprotection et Sûreté Nucléaire, PRP-ENV/SERIS/ LECO, Laboratoire d'Ecotoxicologie des Radionucléides, Saint-Paul-Lez-Durance Cedex 13115, France. ${ }^{7}$ Current address: Univ. Nîmes, Lab. Géochimie Isotopique Environnementale, Nîmes F-30035, France. 
Received: 14 November 2013 Accepted: 18 March 2014

Published: 27 March 2014

\section{References}

1. Barceloux DG: Cobalt. J Toxicol Clin Toxicol 1999, 37:201-206.

2. Kim JH, Gibb HJ, Howe PD: Cobalt and Inorganic Cobalt Compounds. Geneva: WHO Press, World Health Organization; 2006.

3. Lison D: Cobalt - Chapter 25. In Handbook on the Toxicology of Metals. Edited by Nordberg GF, Fowler BA, Nordberg M, Friberg LT. ; 2007:511-528.

4. Le Guen B, Ansoborlo E: Le Cobalt et ses Isotopes [in French]. In Toxicologie-Pathologie professionnelle. Paris: EMC (Elsevier SAS); 2005:16-002C-60.

5. Schroeder WH, Dobson M, Kane DM, Johnson ND: Toxic trace elements associated with airborne particulate matter: a review. Japca 1987, 37:1267-1285.

6. Sabbioni E, Fortaner S, Farina M, Del Torchio R, Petrarca C, Bernardini G, Mariani-Costantini R, Perconti S, Di Giampaolo L, Gornati R, Di Gioacchino M: Interaction with culture medium components, cellular uptake and intracellular distribution of cobalt nanoparticles, microparticles and ions in Balb/3 T3 mouse fibroblasts. Nanotoxicology 2014, 8:88-99.

7. Sabbioni E, Fortaner S, Farina M, Del Torchio R, Olivato I, Petrarca C, Bernardini G, Mariani-Costantini R, Perconti S, Di Giampaolo L, Gornati R, Di Gioacchino M: Cytotoxicity and morphological transforming potential of cobalt nanoparticles, microparticles and ions in Balb/3 T3 mouse fibroblasts: an in vitro model. Nanotoxicology 2014, 8:455-464.

8. Ponti J, Sabbioni E, Munaro B, Broggi F, Marmorato P, Franchini F, Colognato R, Rossi F: Genotoxicity and morphological transformation induced by cobalt nanoparticles and cobalt chloride: an in vitro study in Balb/3 T3 mouse fibroblasts. Mutagenesis 2009, 24:439-445.

9. Peters K, Unger RE, Gatti AM, Sabbioni E, Tsaryk R, Kirkpatrick CJ: Metallic nanoparticles exhibit paradoxical effects on oxidative stress and pro-inflammatory response in endothelial cells in vitro. Int J Immunopathol Pharmacol 2007, 20:685-695.

10. Papis E, Rossi F, Raspanti M, Dalle-Donne I, Colombo G, Milzani A, Bernardini G, Gornati R: Engineered cobalt oxide nanoparticles readily enter cells. Toxicol Lett 2009, 189:253-259.

11. Limbach LK, Wick P, Manser P, Grass RN, Bruinink A, Stark WJ: Exposure of engineered nanoparticles to human lung epithelial cells: influence of chemical composition and catalytic activity on oxidative stress. Environ Sci Technol 2007, 41:4158-4163.

12. Horie M, Fujita K, Kato H, Endoh S, Nishio K, Komaba LK, Nakamura A, Miyauchi A, Kinugasa S, Hagihara Y, Niki E, Yoshida Y, Iwahashi H: Association of the physical and chemical properties and the cytotoxicity of metal oxide nanoparticles: metal ion release, adsorption ability and specific surface area. Metallomics 2012, 4:350-360.

13. Alarifi S, Ali D, AO Y, Ahamed M, Siddiqui MA, Al-Khedhairy AA: Oxidative stress contributes to cobalt oxide nanoparticles-induced cytotoxicity and DNA damage in human hepatocarcinoma cells. Int I Nanomedicine 2013, 8:17-23.

14. Collier CG, Pearce MJ, Hodgson A, Ball A: Factors affecting the in vitro dissolution of cobalt oxide. Environ Health Perspect 1992, 97:109-113.

15. Pujalte I, Passagne I, Brouillaud B, Treguer M, Durand E, Ohayon-Courtes C, L'Azou B: Cytotoxicity and oxidative stress induced by different metallic nanoparticles on human kidney cells. Part Fibre Toxicol 2011, 8:10.

16. Auffan M, Rose J, Wiesner MR, Bottero JY: Chemical stability of metallic nanoparticles: a parameter controlling their potential cellular toxicity in vitro. Environ Pollut 2009, 157:1127-1133.

17. Luyts K, Napierska D, Nemery B, Hoet PHM: How physico-chemical characteristics of nanoparticles cause their toxicity: complex and unresolved interrelations. Environ Sci Processes Impacts 2013, 15:23-38.

18. Christensen JM, Poulsen OM: A 1982-1992 surveillance programme on Danish pottery painters. Biological levels and health effects following exposure to soluble or insoluble cobalt compounds in cobalt blue dyes. Sci Total Environ 1994, 150:95-104.

19. Davis K, Marsh JW, Gerondal M, Bailey MR, Le Guen B: Assessment of intakes and doses to workers followed for 15 years after accidental inhalation of ${ }^{60} \mathrm{Co}$. Health Phys 2007, 92:332-344.

20. Lison D, Buchet JP, Swennen B, Molders J, Lauwerys R: Biological monitoring of workers exposed to cobalt metal, salt, oxides, and hard metal dust. Occup Environ Med 1994, 51:447-450.
21. Foster PP, Pearman I, Ramsden D: An interspecies comparison of the lung clearance of inhaled monodisperse cobalt oxide particles.2. Lung clearance of inhaled cobalt oxide in man. J Aerosol Sci 1989, 20:189-204.

22. Lundborg M, Falk R, Johansson A, Kreyling W, Camner P: Phagolysosomal $\mathrm{pH}$ and dissolution of cobalt oxide particles by alveolar macrophages. Environ Health Perspect 1992, 97:153-157.

23. Forbes II: Human airway epithelial cell lines for in vitro drug transport and metabolism studies. Pharm Sci Technolo Today 2000, 3:18-27.

24. Courcot E, Leclerc J, Lafitte JJ, Mensier E, Jaillard S, Gosset P, Shirali P, Pottier $\mathrm{N}$, Broly F, Lo-Guidice JM: Xenobiotic metabolism and disposition in human lung cell models: comparison with in vivo expression profiles. Drug Metab Dispos 2012, 40:1953-1965C.

25. Bresson C, Darolles C, Carmona A, Gautier C, Sage N, Roudeau S, Ortega R, Ansoborlo E, Malard V: Cobalt chloride speciation, mechanisms of cytotoxicity on human pulmonary cells, and synergistic toxicity with zinc. Metallomics 2013, 5:133-143.

26. Darolles C, Sage N, Armengaud J, Malard V: In vitro assessment of cobalt oxide particle toxicity: Identifying and circumventing interference. Toxicol In Vitro 2013, 27:1699-1710.

27. Xie H, Holmes AL, Wise SS, Gordon N, Wise JP Sr: Lead chromate-induced chromosome damage requires extracellular dissolution to liberate chromium ions but does not require particle internalization or intracellular dissolution. Chem Res Toxicol 2004, 17:1362-1367.

28. Misra SK, Dybowska A, Berhanu D, Luoma SN, Valsami-Jones E: The complexity of nanoparticle dissolution and its importance in nanotoxicological studies. Sci Total Environ 2012, 438:225-232.

29. Horev-Azaria L, Kirkpatrick CJ, Korenstein R, Marche PN, Maimon O, Ponti J, Romano R, Rossi F, Golla-Schindler U, Sommer D, Uboldi C, Unger RE, Villiers C: Predictive toxicology of cobalt nanoparticles and ions: comparative in vitro study of different cellular models using methods of knowledge discovery from data. Toxicol Sci 2011, 122:489-501.

30. Jiang H, Liu F, Yang H, Li Y: Effects of cobalt nanoparticles on human T cells in vitro. Biol Trace Elem Res 2012, 146:23-29.

31. Cronholm P, Karlsson HL, Hedberg J, Lowe TA, Winnberg L, Elinn K, Wallinder IO, Moller L: Intracellular uptake and toxicity of $\mathrm{Ag}$ and $\mathrm{CuO}$ nanoparticles: a comparison between nanoparticles and their corresponding metal ions. Small 2013, 9:970-982.

32. Xia T, Kovochich M, Liong M, Madler L, Gilbert B, Shi H, Yeh Jl, Zink Jl, Nel AE: Comparison of the mechanism of toxicity of zinc oxide and cerium oxide nanoparticles based on dissolution and oxidative stress properties. ACS Nano 2008, 2:2121-2134.

33. Cho WS, Duffin R, Bradley M, Megson IL, Macnee W, Howie SE, Donaldson K: $\mathrm{NiO}$ and $\mathrm{Co} 3 \mathrm{O} 4$ nanoparticles induce lung DTH-like responses and alveolar lipoproteinosis. Eur Respir J 2012, 39:546-557.

34. West MA, Bretscher MS, Watts C: Distinct endocytotic pathways in epidermal growth factor-stimulated human carcinoma A431 cells. J Cell Biol 1989, 109:2731-2739.

35. Conner SD, Schmid SL: Regulated portals of entry into the cell. Nature 2003, 422:37-44

36. Xia T, Kovochich M, Liong M, Zink Jl, Nel AE: Cationic polystyrene nanosphere toxicity depends on cell-specific endocytic and mitochondrial injury pathways. ACS Nano 2008, 2:85-96.

37. Munoz A, Costa M: Elucidating the mechanisms of nickel compound uptake: a review of particulate and nano-nickel endocytosis and toxicity. Toxicol Appl Pharmacol 2012, 260:1-16.

38. Cho WS, Duffin R, Howie SE, Scotton CJ, Wallace WA, Macnee W, Bradley M, Megson IL, Donaldson K: Progressive severe lung injury by zinc oxide nanoparticles; the role of $\mathrm{Zn} 2+$ dissolution inside lysosomes. Part Fibre Toxicol 2011, 8:27.

39. Beck-Speier I, Kreyling WG, Maier KL, Dayal N, Schladweiler MC, Mayer P, Semmler-Behnke M, Kodavanti UP: Soluble iron modulates iron oxide particle-induced inflammatory responses via prostaglandin $E(2)$ synthesis: in vitro and in vivo studies. Part Fibre Toxicol 2009, 6:34.

40. Gehrke H, Pelka J, Hartinger CG, Blank H, Bleimund F, Schneider R, Gerthsen D, Brase S, Crone M, Turk M, Marko D: Platinum nanoparticles and their cellular uptake and DNA platination at non-cytotoxic concentrations. Arch Toxicol 2011, 85:799-812.

41. Ortega R, Bresson C, Fraysse A, Sandre C, Deves G, Gombert C, Tabarant M, Bleuet P, Seznec H, Simionovici A, Moretto P, Moulin C: Cobalt distribution in keratinocyte cells indicates nuclear and perinuclear accumulation and 

$188: 26-32$.

42. Lozano O, Mejia J, Masereel B, Toussaint O, Lison D, Lucas S: Development of a PIXE analysis method for the determination of the biopersistence of $\mathrm{SiC}$ and TiC nanoparticles in rat lungs. Nanotoxicology 2012, 6:263-271.

43. Maxwell P. Salnikow K: HIF-1: an oxygen and metal responsive transcription factor. Cancer Biol Ther 2004, 3:29-35.

44. Saini Y, Kim KY, Lewandowski R, Bramble LA, Harkema JR, Lapres JJ: Role of hypoxia-inducible factor $1\{a l p h a\}$ in modulating cobalt-induced lung inflammation. Am J Physiol Lung Cell Mol Physiol 2010, 298:L139-L147.

45. Lison D, De Boeck M, Verougstraete V, Kirsch-Volders M: Update on the genotoxicity and carcinogenicity of cobalt compounds. Occup Environ Med 2001, 58:619-625.

46. De Boeck M, Kirsch-Volders M, Lison D: Cobalt and antimony: genotoxicity and carcinogenicity. Mutat Res 2003, 533:135-152.

47. Salnikow K, Su W, Blagosklonny MV, Costa M: Carcinogenic metals induce hypoxia-inducible factor-stimulated transcription by reactive oxygen species-independent mechanism. Cancer Res 2000, 60:3375-3378.

48. Pulido MD, Parrish AR: Metal-induced apoptosis: mechanisms. Mutat Res 2003, 533:227-241.

49. Bruick RK: Oxygen sensing in the hypoxic response pathway: regulation of the hypoxia-inducible transcription factor. Genes Dev 2003, 17:2614-2623.

50. Laurent S, Burtea C, Thirifays C, Hafeli UO, Mahmoudi M: Crucial ignored parameters on nanotoxicology: the importance of toxicity assay modifications and "cell vision". PLoS One 2012, 7:e29997.

51. Puck TT, Marcus PI: Action of x-rays on mammalian cells. J Exp Med 1956, 103:653-666.

52. Franken NA, Rodermond HM, Stap J, Haveman J, van Bree C: Clonogenic assay of cells in vitro. Nat Protoc 2006, 1:2315-2319.

53. Marques MRC, Loebenberg R, Almukainzi M: Simulated biological fluids with possible application in dissolution testing. Dissolution Technologies 2011, 18:15-28.

54. Stringer B, Imrich A, Kobzik L: Flow cytometric assay of lung macrophage uptake of environmental particulates. Cytometry 1995, 20:23-32.

55. Boland S, Baeza-Squiban A, Fournier T, Houcine O, Gendron MC, Chevrier M, Jouvenot G, Coste A, Aubier M, Marano F: Diesel exhaust particles are taken up by human airway epithelial cells in vitro and alter cytokine production. Am J Physiol 1999, 276:L604-L613.

56. Des Rieux A, Fievez V, Theate I, Mast J, Preat V, Schneider YJ: An improved in vitro model of human intestinal follicle-associated epithelium to study nanoparticle transport by M cells. Eur J Pharm Sci 2007, 30:380-391.

57. Gratton SE, Ropp PA, Pohlhaus PD, Luft JC, Madden VJ, Napier ME, DeSimone JM: The effect of particle design on cellular internalization pathways. Proc Natl Acad Sci U S A 2008, 105:11613-11618.

58. Lechner JF, LaVeck MA: A serum-free method for culturing normal human bronchial epithelial cells at clonal density. Methods Cell Sci 1985, 9:43-48.

59. Carmona A, Deves G, Ortega R: Quantitative micro-analysis of metal ions in subcellular compartments of cultured dopaminergic cells by combination of three ion beam techniques. Anal Bioanal Chem 2008, 390:1585-1594.

60. Johansson SAE, Campbell JE: PIXE: A Novel Technique for Elemental Analysis. Chichester: John Wiley \& Sons; 1988.

61. Grime GW: The "Q factor" method: quantitative microPIXE analysis using RBS normalisation. Nucl Instrum Methods In Phys Res B Beam Interactions Mater Atoms 1996, 109-110:170-174.

62. Mayer M: SIMNRA user's Guide. Garching: Max-Planck-Inst. für Plasmaphysik; 1997.

63. Campbell JL, Boyd NI, Grassi N, Bonnick P, Maxwell JA: The Guelph PIXE software package IV. Nucl Instrum Methods In Phys Res B Beam Interactions Mater Atoms 2010, 268:3356.

doi:10.1186/1743-8977-11-14

Cite this article as: Ortega et al:: Low-solubility particles and a

Trojan-horse type mechanism of toxicity: the case of cobalt oxide on human lung cells. Particle and Fibre Toxicology 2014 11:14.

\section{Submit your next manuscript to BioMed Central and take full advantage of:}

- Convenient online submission

- Thorough peer review

- No space constraints or color figure charges

- Immediate publication on acceptance

- Inclusion in PubMed, CAS, Scopus and Google Scholar

- Research which is freely available for redistribution

Submit your manuscript at www.biomedcentral.com/submit 